\title{
Coalification and coal alteration under mild thermal conditions
}

\author{
Pavel Straka $^{1}$ Ivana Sýkorová ${ }^{1}$
}

Received: 2 May 2018/Revised: 13 July 2018/Accepted: 30 August 2018/Published online: 12 September 2018

(C) The Author(s) 2018

\begin{abstract}
Coalification temperatures are often considered to be approximately $100-170{ }^{\circ} \mathrm{C}$ for bituminous coal and $170-275^{\circ} \mathrm{C}$ for anthracite. However, our micropetrographic observations, solid state ${ }^{27} \mathrm{Al}$ magic-angle spinning nuclear magnetic resonance measurements, interpretation of $\delta^{13} \mathrm{C}$ values for whewellite in pelosiderite concretions from Carboniferous sediments, and assessment of whewellite thermal stability show that coalification temperatures can be significantly lower. Also the temperatures of coal alteration may be substantially lower than is stated. Ordinarily, hightemperature alteration is reported, but microthermometric measurements of fluids temperatures and micropetrographic observations show that the coal alteration can take place at low temperatures. For this reason, coals from the KladnoRakovník Basin, part of Late Paleozoic continental basins of the Czech Republic, were analyzed. Regarding coalification, micropetrographic characterizations of unaltered coals, the presence of thermally unstable $\mathrm{Al}$ complexes in the coal organic mass documented using ${ }^{27} \mathrm{Al}$ MAS NMR method, and proven occurrence of whewellite in pelosiderite concretions suggest a lower coalification temperature, max. $~ 70{ }^{\circ} \mathrm{C}$. Regarding coal alteration, micropetrographic observations revealed (a) the weaker intensity of fluorescence of liptinite, (b) mylonitic structures and microbreccia with carbonate fluid penetration, and (c) high oxygen content in coals (37-38 wt.\%). These phenomena are typical for thermal and oxidative alteration of coal. As the temperature of carbonate fluids inferred from fluid inclusion analysis was evaluated as $\sim 100-113{ }^{\circ} \mathrm{C}$, the temperature of coal alteration was suggested as $\sim 113{ }^{\circ} \mathrm{C}$; the alteration was caused by hot hydrothermal fluids.
\end{abstract}

Keywords Coalification · Thermal and oxidative alteration · Kladno-Rakovník Basin · Al complexes $\cdot{ }^{27} \mathrm{Al}$ MAS NMR . Fluid inclusions $\cdot \delta^{13} \mathrm{C} \cdot$ Whewellite

\section{Introduction}

\subsection{Temperatures of coalification and coal alteration}

The temperatures of coalification are frequently reported as approximately $100-170{ }^{\circ} \mathrm{C}$ for bituminous coal (e.g. Tay-

Electronic supplementary material The online version of this article (https://doi.org/10.1007/s40789-018-0220-7) contains supplementary material, which is available to authorized users.

Pavel Straka

straka@irsm.cas.cz

1 Institute of Rock Structure and Mechanics, v.v.i, The Czech Academy of Sciences, V Holešovičkách 41, 18209 Prague 8, Czech Republic lor et al. 1998) and $170-250{ }^{\circ} \mathrm{C}$ or even $200-275^{\circ} \mathrm{C}$ for anthracite (Taylor et al. 1998; Daniels et al. 1994). However, recent results of instrumental measurements, namely the presented identification of $\mathrm{Al}$ complexes with organic ligands in coal organic mass using solid state ${ }^{27} \mathrm{Al}$ MAS NMR (Straka 2016) and the $\delta^{13} \mathrm{C}$ values for pelosiderite concretions (Žák and Skála 1993), show that coalification temperatures can be significantly lower. Similarly, 
temperatures of coal alteration may be significantly lower than is usually stated. Frequently, a high-temperature alteration of coal is reported (Golab et al. 2007; Sarana and Kar 2011), but recent measurements using microthermometry (Zachariáš and Pešek 2011) and the presented micropetrographic observations show that the alteration of coal can proceed as a low-temperature process. To demonstrate these phenomena, coal samples from the Kladno-Rakovník Basin were analyzed. Coal from this basin represents a common bituminous coal, and this basin is worked out for its paleo-heat flow and paleogeothermal gradient and the coal samples have been subjected to microthermometric measurements.

The essential factors in the coalification of organic matter are temperature, heating rate, time and pressure, with fossil temperature being crucial. Chemically, coalification is a long-term low-temperature high-pressure pyrolysis-like decomposition of organic matter with the continuous escape of gaseous products. Under atmospheric pressure $(\sim 0.1 \mathrm{MPa})$, it begins at $\sim 230{ }^{\circ} \mathrm{C}$ (Basu 2010), according to other data at $\sim 280{ }^{\circ} \mathrm{C}$ (Demirbas 2009). Nevertheless, increased pressure in general facilitates the thermal decomposition of organic matter (Landais and Gérard 1996) and higher- or high-pressure confined pyrolysis yields results comparable to those of natural maturation (Landais et al. 1990). Therefore, if the pressure increases by $25-30 \mathrm{MPa}$ per $1 \mathrm{~km}$ of depth, organic matter decomposition may occur at substantially lower temperatures, $120^{\circ} \mathrm{C}$ (Šafanda et al. 2003), or $70{ }^{\circ} \mathrm{C}$ (Given 1988), or $85-95{ }^{\circ} \mathrm{C}$ (Straka and Náhunková 2009). Moreover, higher pressure results in a higher yield of the solid carbonaceous phase (Noumi et al. 2015). It can be deduced, unlike most authors' opinions (Daniels et al. 1994; Taylor et al. 1998), that the temperatures of coal formation are not $100-170{ }^{\circ} \mathrm{C}$ or $170-250{ }^{\circ} \mathrm{C}$ or even $200-275{ }^{\circ} \mathrm{C}$, but substantially lower.

In the present investigation, special attention is paid to Al complexes with organic ligands, which are an integral part of organic matter and coal organic mass (Bouška, 1981; Bouška et al. 2000; Straka and Klika 2006; Straka 2016). These complexes (see Supplementary material, point 1, Figs I and II) are thermally unstable and decompose at a temperature of ca $90-95{ }^{\circ} \mathrm{C}$ (Straka 2016), therefore, their positive identification in coal organic mass using an analysis of the ${ }^{27} \mathrm{Al}$ MAS NMR spectra indicates that the mentioned temperature could not be attained during coalification. Otherwise, they would not be present in the organic mass of coal.

Coal alteration usually occurs at high-temperature as reported by several authors (Golab and Carr 2004; Golab et al. 2007; Yao et al. 2011; Sarana and Kar 2011; Kus 2017). Sarana and Kar (2011) report that the coal bands affected by intrusives suffered through a temperature up
$500{ }^{\circ} \mathrm{C}$ as was indicated on the basis of the presence of unaltered pyrite. Kus (2017) states that the oxidative and thermal alteration of coal is induced by a high-temperature regime at temperatures over $800{ }^{\circ} \mathrm{C}$. However, besides high-temperature alteration, Stukalova and Rusinova (2007) consider also low-temperature alteration: at the contact of the Early Cretaceous coal with a diabase dike (coal-intrusive contact), the high-temperature alteration of coal organic mass took place, but farther away from the dike, the coal was altered by low-temperature hydrothermal metamorphism. The coal in direct contact with the dike had properties typical of anthracites: strong anisotropy and high random vitrinite reflectance values $\left(R_{r} 3.8 \%-5.5 \%\right)$, unlike the low thermally altered coal at a certain distance from the dikes $\left(R_{r} 2.0 \%-2.5 \%\right)$. Thus, the local high-temperature transformation of the coal organic mass at the dike contacts was followed by a relatively low-temperature hydrothermal metamorphism of the coal. Altered coal often contains carbonates (see Supplementary material, point 2).

In the case of coal from the Kladno-Rakovník Basin, a visible alteration of the coal's organic mass around carbonate-dominated veins and veinlets, manifested by the loss of coal brightness (change in greyscale), was observed (Zachariáš and Pešek 2011). Based on the work (Klika and Osovský 1999), we have considered thermal and oxidative alteration. Thermally and oxidatively altered coals have much higher oxygen at the expense of carbon and hydrogen in comparison with unaltered ones, and, further, the thermal and oxidative altered coals have a little difference in the random vitrinite reflectance compared with that of unaltered coal.

\subsection{Aim and layout of the article}

The aim of the presented work is to demonstrate the low temperature conditions of the coalification and coal alteration in the Kladno-Rakovník Basin coals.

In this work, the temperature conditions of coalification are evaluated using micropetrographic observations and determined by the solid-state ${ }^{27} \mathrm{Al}$ nuclear magnetic resonance of $\mathrm{Al}$ complexes with organic ligands present in coal organic mass. Further, the $\delta^{13} \mathrm{C}$ values and thermal stability of whewellite from Carboniferous sediments of the Kladno-Rakovník Basin were taken into account; due to limited thermal stability of whewellite, its proven existence implies that coalification could occur at significantly lower temperatures than expected.

The low temperature conditions of coal alteration are evaluated using the micropetrographic observations of oxidatively and thermally altered samples and determined using data analysis on fluid inclusions in carbonate-dominated veins/veinlets from the Kladno-Rakovník Basin, 
Upper Radnice Coal Seam, previously measured by microthermometry (Zachariáš and Pešek 2011).

\section{Study area}

\subsection{Kladno-Rakovník Basin, Czech Republic}

The Kladno-Rakovník Basin is one of the sedimentary basins of the Bohemian Massif that began to form in the Late Carboniferous during the Variscan Orogeny. Crustal extension and mantle-lithosphere attenuation is responsible for the Late Permian and latter subsidence and sediment accumulation in some Permo-Carboniferous troughs such as the Bohemian Massif (McCann et al. 2006).

The Kladno-Rakovník Basin is part of Late Paleozoic continental deposits of the Czech Republic evolved in two periods: the late Bashkirian and the late Moscovian period, and the Gzhelian and Cisurian period. The Late Paleozoic continental deposits cover an area of more than $11,000 \mathrm{~km}^{2}$ and consist largely of a belt of several tens of kilometers wide and nearly $300 \mathrm{~km}$ long, ranging from the west of the Czech Republic to its northeast border with Poland (Fig. 1). The belt is subdivided into two parts: the Central and Western Bohemian Basins, located on the Cadomian basement of the Teplá-Barrandien Zone and the Sudetic Basins, situated on the Saxo-Thuringian block. The Central and Western Bohemian Basins are subdivided into the Pilsen, Manětín, Žihle, Radnice, Kladno-Rakovník and
Mšeno-Roudnice Basins. These basins previously formed a part of a single common depocenter with the same history of sedimentation and sharing the same lithostratigraphic subdivision (Opluštil 2005; Opluštil et al. 2013, 2016). Its biostratigraphy is published by Pešek (2004) and Opluštil et al. (2016). Stratigraphic succession of the study area is provided in Table 1 (according to Pešek and Sýkorová 2006, adapted). (The formations in Table 1 are both grey and red, as the basin sediments in Central and Western Bohemia are characterized by climatically controlled alteration of grey (coal-bearing) and red (coal-barren) strata (Opluštil 2005). Tested samples originated from the Upper Radnice Coal Seam, the Radnice Member, the Radnice group of seams.)

The Kladno-Rakovník Basin borders the northern part of the Žihle Basin (Fig. 1) and comprises four formations (Westfalian C-Upper Stephanian/Autunian), whose total thickness exceeds $1400 \mathrm{~m}$ (Pešek 2004; Opluštil et. al. 2013). The Upper Carboniferous successions, containing coal seams and refractory claystones are largely covered by Upper Cretaceous sediments. The Upper Carboniferous coals from the Kladno-Rakovník Basin were studied intensively in the past (Opluštil et al. 1999; Pešek et al. 2001; Pešek 2004; Pešek and Sivek 2012), but more recently attention is focused on the altered coals and the investigation of the conditions of their formation with the aim to understand the temperatures of coal formation and alteration (Zachariáš and Pešek 2011).

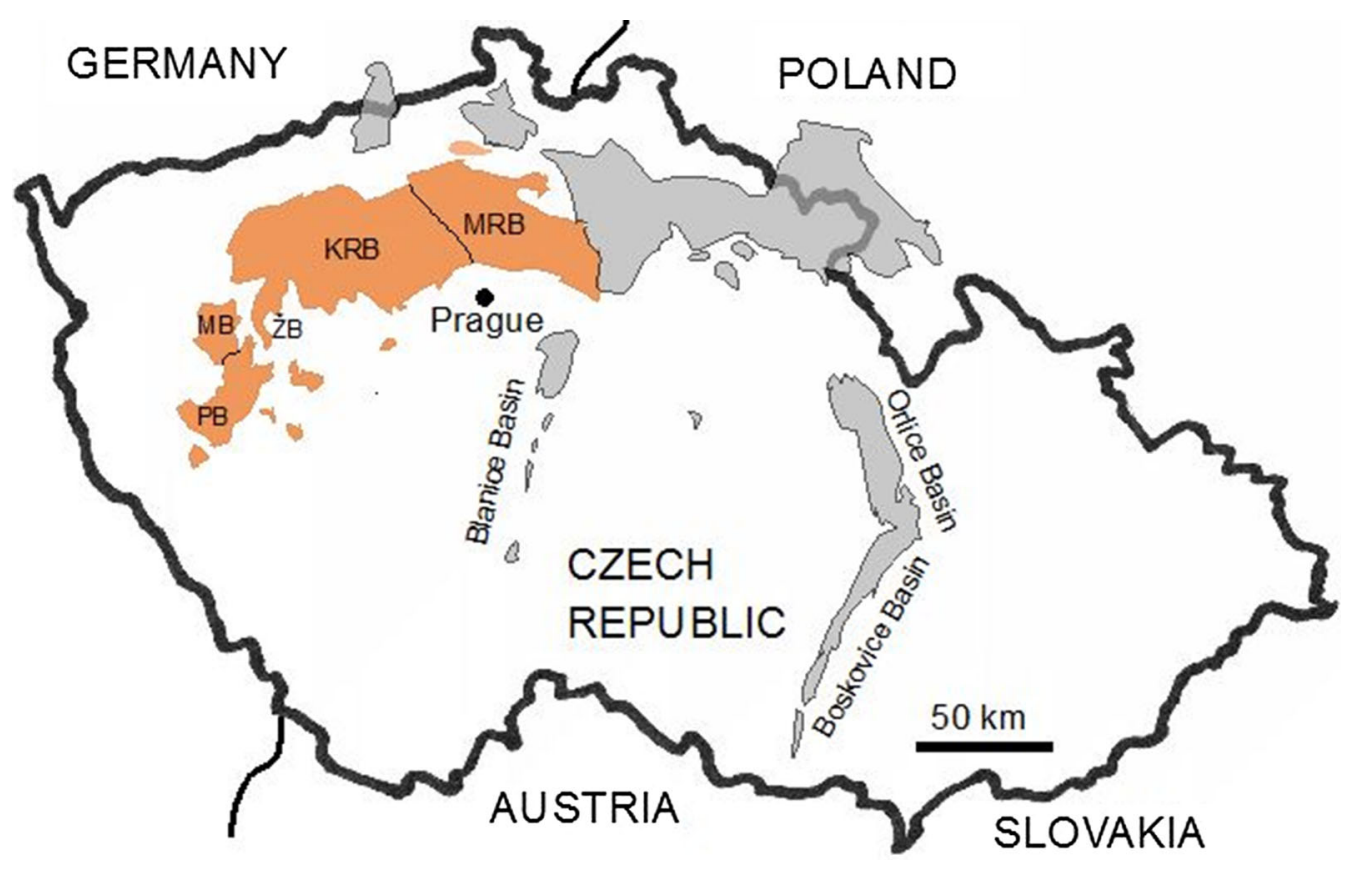

Fig. 1 Late Paleozoic continental basins of the Czech Republic. KRB Kladno-Rakovník. Basin, MRB Mšeno-Roudnice Basin, ŽB Žihle Basin, $M B$ Manětín Basin, $P B$ Pilsen Basin (marked in orange: the Central and Western Bohemian Basins; marked in grey: Sudetic Basins: Lusatian and Intra-Sudetic Basins) 
Table 1 Lithostratigraphic units of the Kladno-Rakovník Basin (according to Pešek and Sýkorová 2006, adapted)

\begin{tabular}{|c|c|c|c|c|}
\hline \multirow[t]{2}{*}{ Age } & & \multicolumn{3}{|l|}{ Local unit } \\
\hline & & Formation & Member & Group of seams \\
\hline \multirow[t]{4}{*}{ Stephanian } & $\mathrm{C}$ & Líně (upper red) & & \\
\hline & & Hiatus & & \\
\hline & B & Slaný (upper grey) & Kounov & Kounov \\
\hline & & & Ledce Malešice Jelenice & Mělník \\
\hline \multirow[t]{2}{*}{ Stephanian } & Barruelian & Týnec (lower red) & & \\
\hline & Cantabrian & Kladno (lower grey) & Nýřany & Nevřeň \\
\hline \multirow[t]{4}{*}{ Westphalian } & Asturian & & & Chotíkov \\
\hline & & & & Nýřany \\
\hline & & & & Touškov \\
\hline & & Hiatus & & \\
\hline \multirow[t]{3}{*}{ Westphalian } & Bolsovian & Kladno (lower grey) & Radnice & Lubná \\
\hline & & & & Radnice \\
\hline & & & & Plzeň \\
\hline
\end{tabular}

\subsection{Paleogeothermal gradient and paleo-heat flow in Central Bohemian basins}

An important parameter for the assessment of the coalification temperature in a sedimentary basin is the paleogeothermal gradient. Research into paleogeothermal gradients of sedimentary basins in the Czech Republic points to $45-53{ }^{\circ} \mathrm{C} / \mathrm{km}$ for the Central Bohemian PermoCarboniferous basins (Šafanda et al. 1990), with higher paleogeothermal gradients in the Boskovice furrow $\left(77^{\circ} \mathrm{C} /\right.$ $\mathrm{km}$ in its northern part and $72{ }^{\circ} \mathrm{C} / \mathrm{km}$ in its southern part) and the Ostrava Formation of the Upper Silesian Basin (95 ${ }^{\circ} \mathrm{C} / \mathrm{km}$ for Namurian A), as well as paleogeothermal gradients for the Karviná Formation of the Upper Silesian Basin $\left(60-77^{\circ} \mathrm{C} / \mathrm{km}\right.$ for Namurian B - Westphalian A) (Šafanda and Malý 1994). These significant differences in paleogeothermal gradients may be explained by different paleo-geothermal heating of the sedimentary strata following the sediment accumulation. The different paleogeothermal heating can be caused by an increased subsidence or stronger paleo-heat flow, represented among others by volcanic activity and endogenous radioactivity. Paleogeothermal gradients largely influenced the coalification (Hower and Gayer 2002).

Coalification is primarily a result of the process of organic matter maturation related to an increase in temperature (Barker 1989; Singh and Singh 1998; Singh et al 2016), which is a consequence of paleo-heat flow. For the Central Bohemian basins, paleo-heat flows ranging between 96 and $117 \mathrm{~mW} / \mathrm{m}^{2}$ were established by Šafanda et al. (1990) during the Permo-Carboniferous. For comparison, Littke et al. (1994) studied the paleo-heat flows and thicknesses of the eroded Carboniferous overburden in the coal-bearing Ruhr basin (Germany) and report paleoheat flows for the time of maximum burial, most probably in the Stephanian, ranging from 64 to $83 \mathrm{~mW} / \mathrm{m}^{2}$; Hertle and Littke (2000) calculated paleo-heat flows between 50 and $75 \mathrm{~mW} / \mathrm{m}^{2}$ in the Saar Basin (Germany) during the deep burial in the Permo-Carboniferous, Botor and Littke (2003) report the value of $80 \mathrm{~mW} / \mathrm{m}^{2}$ in the Lublin Basin (Poland) in the Late Carboniferous and Geršlová et al. (2016) calculated a paleo-heat flow of $75-80 \mathrm{~mW} / \mathrm{m}^{2}$ in the Upper Silesian Coal Basin (Czech Republic) during the Late Carboniferous. In contrast, based on an analysis of 45 coal samples, Copard et al. (2000) established paleo-heat flow in the Brive Basin (Massif Central, France) as high as 100 and $120 \mathrm{~mW} / \mathrm{m}^{2}$ during the Stephanian and in the Bosmoreau-les-Mines Basin of 150 and $180 \mathrm{~mW} / \mathrm{m}^{2}$ during the Late Carboniferous. The authors conclude that the Massif Central was subjected to a hyperthermal regime in the Stephanian due to crustal thinning following thickening of the Variscan crust during the Devonian-Carboniferous collisional episodes. In light of these findings it is possible to qualify the mentioned paleo-heat flow in the Central Bohemian basins $\left(96-117 \mathrm{~mW} / \mathrm{m}^{2}\right)$ as quite high.

Previous studies of the coalification patterns in the $\mathrm{K}$ ladno-Rakovník Basin (Daněk et al. 2002; Šafanda et al. 2003; Pešek and Sýkorová 2006) showed that the coalification was relatively fast in this case, taking place at depths ranging from only tens of meters to several hundred meters below the earth's surface, and relatively short periods of several hundred thousand years up to about 2 Ma. Nevertheless, this requires appropriate heat flow through the 
basin, allowing the required temperature to be reached. The mentioned $96-117 \mathrm{~mW} / \mathrm{m}^{2}$ appears to be sufficient.

\section{Materials and analytical procedures}

\subsection{Materials}

For the analyses, eleven samples of bituminous coal from the Kladno-Schoeller mine in the Kladno-Rakovník Basin, the Kladno Valley, were chosen; the samples were selected from both banded and mineralized coals of Bolsovian age, originating from the Upper Radnice Coal Seam, the Radnice Group of seams, the Radnice Member, $600 \mathrm{~m}$ below the present surface. For the location of the sampling, see Supplementary material, point 3, Figs III and IV.

From the samples, eleven polished sections were prepared (K1-K11) in order to determine their vitrinite reflectance and maceral composition. Other coal samples were prepared for solid-state ${ }^{27} \mathrm{Al}$ MAS NMR analysis (powdered samples) and chemical and thermogravimetric analyses $(<0.2 \mathrm{~mm})$. The elemental composition, rank and maceral composition of all the samples are summarized in Tables 2 and 3.

\subsection{Analytical procedures}

The vitrinite reflectance of the samples was measured according to ISO 7404-5 (2009a, b), by a microscopespectrophotometer AXIO Imager M2 m, Zeiss, equipped with an oil immersion objective lens $(40 \times)$ in monochromatic light $(\lambda=546 \mathrm{~nm})$, and calibrated with sapphire ( $R=0.596 \%)$, yttrium aluminum garnet $(R=0.894 \%)$ and N-LASF 46A $(R=1.309 \%)$ standards. The minimal, maximum and random vitrinite reflectance $\left(R_{r}\right)$ and deviations from standards $(\sigma)$ were measured. The maceral composition was determined according to ISO 7404-3 $(2009 a, b)$ and ICCP $(1998,2001)$ and with regard to the works (Taylor et al. 1998; Pickel et al. 2017), on the Olympus BX51 microscope with Zeiss Photomultiplier MK3 system and fluorescence mode, using an immersion lens with $40 \times$ magnification. The Pelton point counter was used for the maceral analysis.

Table 2 Elemental composition of the coal samples Kladno K1 (unaltered coal) and K4 (thermally and oxidatively altered coal) (dry ash free basis)

\begin{tabular}{llllll}
\hline Sample & $\mathrm{C}$ & $\mathrm{H}$ & $\mathrm{N}$ & $\mathrm{S}$ & $\mathrm{O}$ \\
\hline $\mathrm{K} 1$ & 77.68 & 4.46 & 1.89 & 0.00 & 15.97 \\
$\mathrm{~K} 4$ & 58.62 & 2.56 & 1.11 & 0.00 & 37.71 \\
\hline
\end{tabular}

Coal samples K1 and K2 were further analyzed by solidstate ${ }^{27} \mathrm{Al}$ nuclear magnetic resonance $\left({ }^{27} \mathrm{Al}\right.$ MAS NMR). Using this method, aluminum complexes with organic ligands in coal organic mass were identified according to (Straka 2016) and with regard to the works (Howarth et al. 1987; Kirkpatrick 1988; Burchil et al. 1991; Kanehashi and Saito 2004; Smith and van Eck 1999; MacKenzie and Smith 2002; Freitas et al. 2007). The solid-state ${ }^{27} \mathrm{Al}$ MAS NMR spectra were recorded using a Bruker Avance 500 WB/US NMR spectrometer (Karlsruhe, Germany) with 4-mm double-resonance probe heads at the MAS rate of $\omega_{\mathrm{r}}$ ' $2 \pi=11 \mathrm{kHz}$. The spectra were acquired at $130.287 \mathrm{MHz}$, using a tip angle of 20 degrees ( $1 \mu$ s pulse length) with a recycle delay of $2 \mathrm{~s}$. The spectra were referenced to $\mathrm{Al}\left(\mathrm{NO}_{3}\right)_{3}$ at $0.0 \mathrm{ppm}$. For other information on the use of ${ }^{27}$ Al MAS NMR method, see Supplementary material, point 4 . Determination of aluminum in coal organic mass of samples $\mathrm{K} 1$ and $\mathrm{K} 2$ was carried out with an X-ray fluorescence spectrometer EDS Spectro X-Lab, Spectro Analytical Instruments, Kleve; the Al content was $\sim 1 \mathrm{wt} . \%$ in both cases.

For the control of the clay minerals in the coal samples, $\mathrm{X}$-ray analysis was carried out using a Bruker D8 Discover diffractometer with $\mathrm{CuK} \alpha$ radiation, at a voltage of $40 \mathrm{kV}$ and a current of $40 \mathrm{~mA}$, with a LynxEye detector, in the range of $3-69^{\circ} 2$ Theta. The minerals were evaluated using the database Mineral Powder Diffraction Data-Data Book (1980). The organic elemental analysis was performed on a Flash 1112 EA analyzer (Thermo Finnigan, Rodano).

\subsection{Complementary analyses}

The thermal behavior of the coal samples was tested by the thermogravimetric method (Straka et. al. 2014), see Supplementary material, point 5, Figs V and VI. The sedimentation conditions in the arid and oxidizing environment in the Kladno-Rakovník Basin were described using microlithotype analysis, see Supplementary material, point 6, Figs VII-X.

\section{Results and discussion}

\subsection{Elemental composition of organic mass of unaltered and altered coal samples}

Firstly, the altered and unaltered coals were differentiated. Usually, the alteration of the coal is assessed by a visible loss of coal brightness, which is visually observed. Beside this, the thermally and oxidatively altered samples were identified by changes in the elemental composition of the coal organic mass; typical changes in this composition are shown in Table 2. In comparison with the unaltered coal 
Table 3 Rank and maceral composition of the Kladno coal samples K1-K11

\begin{tabular}{|c|c|c|c|c|c|c|c|c|c|c|c|}
\hline \multirow{2}{*}{$\begin{array}{l}\text { Coal } \\
\text { Sample no. }\end{array}$} & \multicolumn{3}{|c|}{ Unaltered } & \multicolumn{4}{|c|}{ Altered } & \multicolumn{4}{|c|}{ Altered, with mylonite and microbreccia } \\
\hline & $\mathrm{K} 1$ & $\mathrm{~K} 2$ & $\mathrm{~K} 3$ & $\mathrm{~K} 4$ & K5 & K6 & K7 & K8 & K9 & K10 & K11 \\
\hline$R_{\mathrm{r}}(\%)$ & 0.68 & 0.66 & 0.67 & 0.67 & 0.65 & 0.69 & 0.67 & 0.66 & 0.68 & 0.69 & 0.69 \\
\hline$\sigma$ & 0.07 & 0.05 & 0.08 & 0.05 & 0.04 & 0.08 & 0.05 & 0.07 & 0.03 & 0.06 & 0.07 \\
\hline Vitrinite (vol.\%) & 71.4 & 61.1 & 51.7 & 27.2 & 43.3 & 51.9 & 53.7 & 31.2 & 44.1 & 36.6 & 46.5 \\
\hline Telinite & 0.0 & 0.0 & 0.0 & 0.0 & 0.0 & 0.0 & 0.0 & 0.0 & 0.0 & 0.0 & 0.0 \\
\hline Collotelinite & 59.3 & 44.8 & 33.2 & 22.6 & 35.2 & 46.2 & 43.4 & 21.9 & 30.6 & 29.0 & 21.0 \\
\hline Vitrodetrinite & 2.4 & 0.8 & 2.1 & 1.0 & 0.7 & 1.3 & 1.3 & 5.5 & 7.3 & 7.6 & 19.3 \\
\hline Collodetrinite & 8.5 & 13.1 & 12.9 & 3.6 & 6.3 & 3.5 & 7.6 & 3.1 & 4.2 & 0.0 & 4.4 \\
\hline Corpogelinite & 1.2 & 2.4 & 3.5 & 0.0 & 1.1 & 0.9 & 1.4 & 0.7 & 2.0 & 0.0 & 1.8 \\
\hline Gelinite & 0.0 & 0.0 & 0.0 & 0.0 & 0.0 & 0.0 & 0.0 & 0.0 & 0.0 & 0.0 & 0.0 \\
\hline Liptinite (vol.\%) & 6.5 & 9.0 & 10.2 & 3.6 & 6.0 & 9.5 & 7.8 & 8.7 & 5.2 & 2.3 & 1.7 \\
\hline Sporinite & 2.4 & 3.3 & 5.3 & 3.0 & 2.2 & 5.1 & 3.2 & 1.5 & 2.9 & 0.0 & 1.5 \\
\hline Cutinite & 0.0 & 0.4 & 0.0 & 0.6 & 0.2 & 0.9 & 0.0 & 0.7 & 0.0 & 0.0 & 0.0 \\
\hline Alginite & 1.2 & 0.3 & 1.1 & 0.0 & 0.7 & 0.9 & 0.7 & 0.1 & 0.0 & 0.0 & 0.0 \\
\hline Resinite & 0.8 & 0.5 & 0.6 & 0.0 & 1.2 & 1.3 & 2.7 & 1.8 & 1.2 & 2.1 & 0.2 \\
\hline Liptodetrinite & 2.1 & 4.5 & 1.5 & 0.0 & 1.7 & 2.2 & 2.7 & 3.1 & 0.6 & 0.0 & 0.0 \\
\hline Bituminite & 0.0 & 0.0 & 1.7 & 0.0 & 0.0 & 0.0 & 0.0 & 1.6 & 0.4 & 0.2 & 0.0 \\
\hline Inertinite(vol.\%) & 17.7 & 19.5 & 22.5 & 12.8 & 17.4 & 25.5 & 18.0 & 10.9 & 8.3 & 0.8 & 8.8 \\
\hline Fusinite & 7.3 & 0.8 & 3.1 & 4.6 & 7.0 & 6.9 & 4.5 & 3.9 & 3.1 & 0.0 & 3.5 \\
\hline Semifusinite & 6.0 & 11.4 & 8.2 & 2.1 & 4.8 & 5.2 & 5.3 & 1.5 & 1.1 & 0.8 & 0.9 \\
\hline Macrinite & 1.2 & 2.4 & 2.1 & 1.5 & 1.6 & 3.5 & 2.2 & 2.1 & 1.0 & 0.0 & 1.8 \\
\hline Funginite & 0.8 & 0.4 & 1.2 & 0.0 & 1.1 & 0.4 & 0.6 & 0.3 & 0.0 & 0.0 & 0.0 \\
\hline Secretinite & 0.0 & 0.0 & 0.9 & 0.0 & 0.0 & 0.9 & 0.4 & 0.0 & 0.0 & 0.0 & 0.0 \\
\hline Micrinite & 0.5 & 0.0 & 1.3 & 2.0 & 0.7 & 0.0 & 0.6 & 0.1 & 0.1 & 0.0 & 0.0 \\
\hline Inertodetrinite & 1.9 & 4.5 & 5.7 & 2.6 & 2.2 & 8.6 & 4.4 & 3.0 & 3.0 & 0.0 & 2.6 \\
\hline Minerals (vol.\%) & 4.4 & 10.4 & 15.6 & 43.6 & 33.3 & 13.1 & 20.5 & 49.2 & 42.4 & 60.3 & 43.0 \\
\hline
\end{tabular}

K1, the sample of altered coal K4 had much higher oxygen at the expense of carbon and hydrogen. Further, the formation of thermodynamically more stable structures during thermal and oxidative alteration of coal organic mass (Kurková 2002; Hosoya et al. 2009; Straka and Havelcová 2012) is reflected in the TG curves of the altered coals (Supplementary material, point 5, Figs V and VI).

\subsection{Micropetrographic observations}

\subsubsection{Overall characteristics}

The studied coals samples (K1-K11, Table 3) are highvolatile bituminous in rank, with variable mineralization and high vitrinite, variable inertinite and low liptinite contents, while the reflectance $R_{r}$ varies between $0.65 \%$ and $0.69 \%$. The collection of samples comprises three samples of unaltered coal (K1-K3), four samples of altered coal (K4-K7) and four samples of altered coal with mylonite structures and microbreccia (K8-K11). Unaltered coals show as their typical features a dominant content of vitrinite, high content of inertinite and low content of minerals (carbonates). The alteration of the coal organic mass is manifested by the weaker intensity of the fluorescence of liptinite macerals (Stach et al. 1982; Pickel et al. 2017). For further consideration, it is important that the thermal alteration significantly increases the $R_{r}$ values, on the contrary, the low thermal and oxidative alteration changes the $R_{r}$ only slightly (Klika and Krausová 1993; Klika 1999; Klika and Osovský 1999), but changes in the reflectance of collotelinite should also be considered. Samples K8-K11 show mylonite structures as well as microbreccia, which are typical symptoms of microtectonics and thermal and oxidative alteration (Klika and Krausová 1993; Gayer et al. 1996; Sýkorová et al. 1996) due to hydrothermal fluids. 


\subsubsection{Unaltered samples}

Samples K1-K3 (Table 3) correspond to the typical bituminous coal with massive bands of collotelinite (Fig. 2), which alternate with the positions of collodetrinite with dispersed macerals of liptinite and inertinite (Fig. 3). The liptinite macerals are dominated by sporinite and liptodetrinite, with alginite and resinite being less frequent. Among the macerals of the inertinite group, fusinite and semifusinite are prevalent, with macrinite and inertodetrinite being less frequent, funginite and micrinite occur rarely. Minor failures were observed in the samples like cracks filled with carbonate and fragments of coal. Carbonates form the dominant share of the mineral substances, rarely, pyrite framboids were observed $(0.8$ vol. $\%)$. No evidence of thermal alteration was observed. Because of the high collotelinite content (Table 3) where the Al complexes with organic ligands are concentrated (Straka 2016), and the absence of clay minerals, samples K1 and K2 were further examined by the ${ }^{27} \mathrm{Al}$ MAS NMR method with the aim to find the likely coalification temperature (see Sect. 4.3.2). (In this case, the sample for ${ }^{27} \mathrm{Al}$ MAS NMR must not contain clay minerals which would disturb the identification of the Al complexes in coal organic mass.)

\subsubsection{Thermally and oxidatively altered samples}

The values of the reflectance $R_{r}$ recorded with samples K4$\mathrm{K} 7$ in the narrow interval from $0.65 \%$ to $0.69 \%$ imply a low thermal and oxidative alteration of coal (Klika and Krausová 1993; Gayer et al. 1996; Sýkorová et al. 1996), probably caused by carbonate fluids (Zachariáš and Pešek 2011). The low alteration of the coal is evidenced by the weaker intensity of the fluorescent color of liptinite (Stach

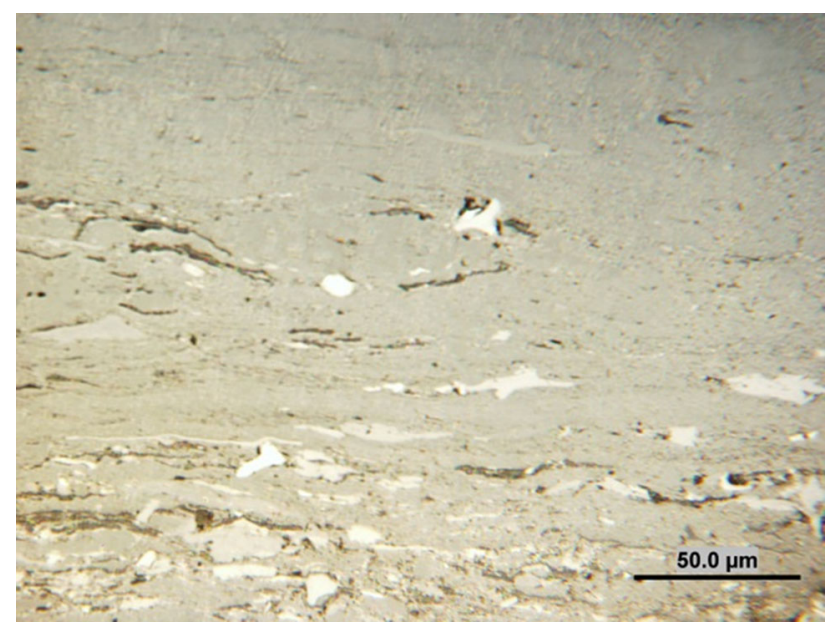

Fig. 2 Collotelinite passing gradually into the collodetrinite with dispersed sporinite, macrinite, fusinite and inertodetrinite

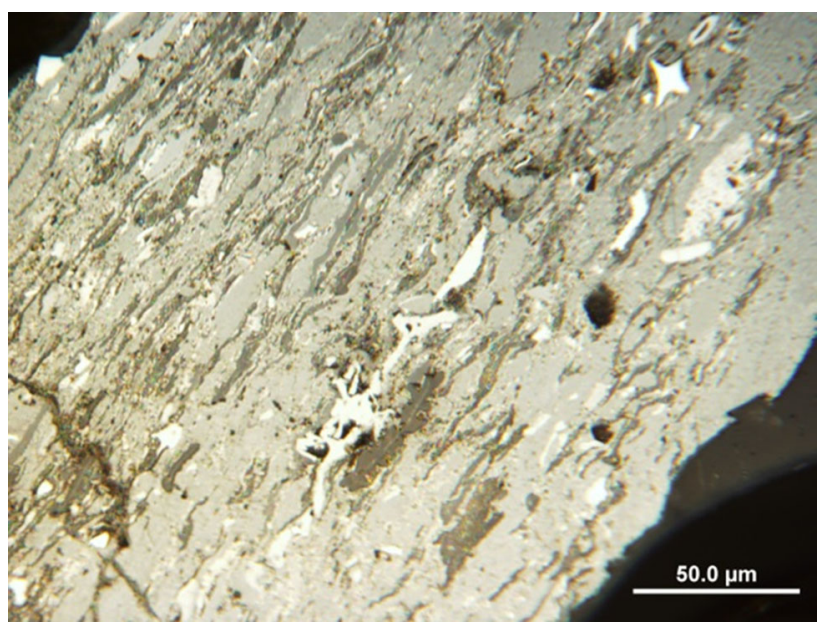

Fig. 3 Collodetrinite with sporinite and whitish inertinite macerals: fusinite, macrinite, inertodetrinite and micrinite

et al. 1982; Pickel et al. 2017). The samples K4-K7 of mineralized coal comprise dominantly of collotelinite (Fig. 4), a variable content of inertinite macerals and a high mineral content (Table 3). In comparison with collotelinite, the amount of collodetrinite is much lower while telinite and gelinite were not found. The most common inertinite maceral is fusinite, less common include semifusinite, macrinite, inertodetrinite as well as micrinite. The samples show numerous cracks filled with carbonate and quartz. The penetration of carbonate disrupts the coal layer, resulting in (a) massive cracks (Fig. 5) or their network filling with carbonate, (b) low altered vitrinite with the occurrence of fine pores and cracks (Fig. 6) almost like in the case of mylonite, (c) a shift of layers like in a tectonic fault, and (d) the porous nature of the megaspores. The samples K4-K7 are evaluated as low thermally and oxidatively altered.

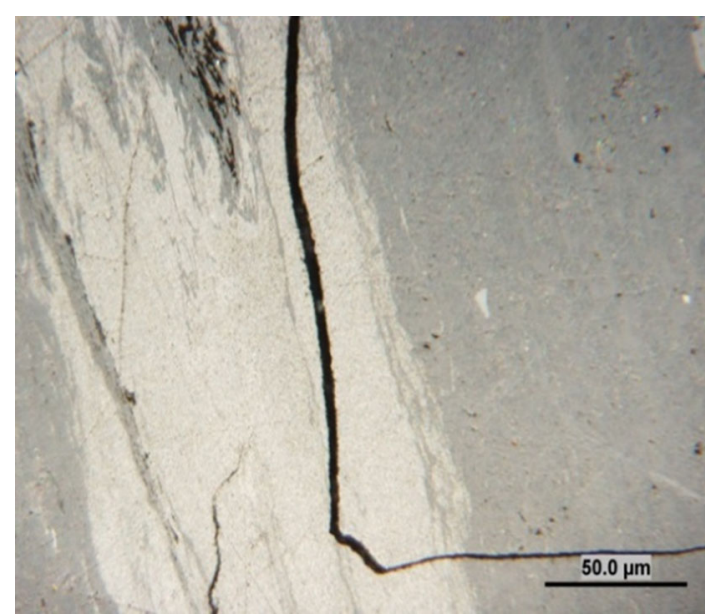

Fig. 4 Collotelinite with the belt of finely grained micrinite and dark cellular structures 


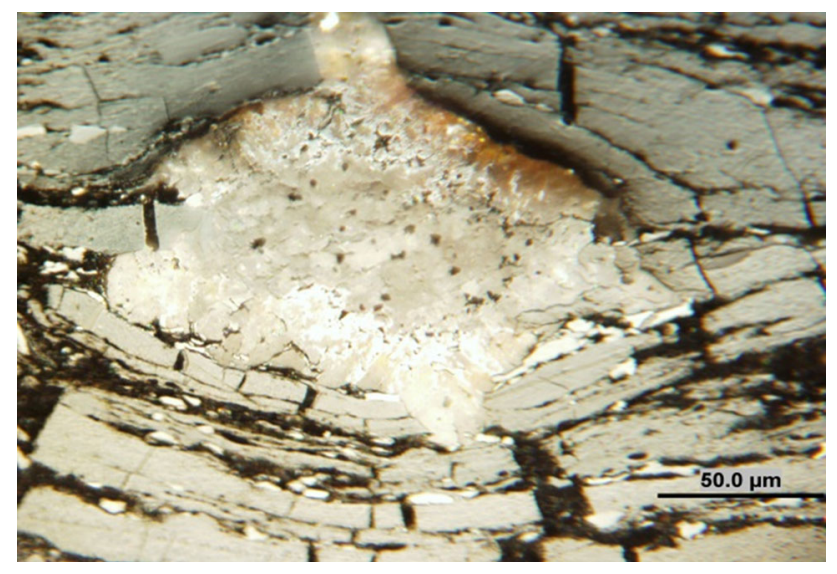

Fig. 5 Calcite and siderite body in the crack of vitrinite

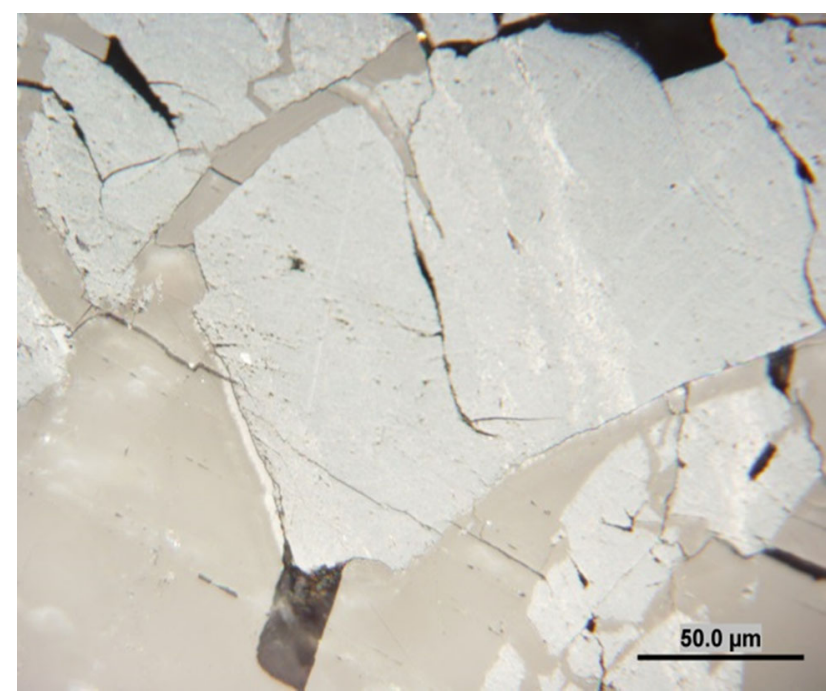

Fig. 6 Low altered vitrinite with micrinite, faulted by carbonatefilled cracks

It is possible to estimate the sedimentation conditions in the original peat bog in connection with the temperature conditions. The high content of collotelinite (up to 59 vol.\%, Table 3) with a discernible cellular structure of plant tissues indicates a humid environment and woody plant vegetation, whereas the higher content of collodetrinite (up to $13 \mathrm{vol} \%$, Table 3 ) indicates the subsequent intensive degradation of this woody plant vegetation or the decomposition of a higher amount of herbaceous vegetation. The observed increased liptinite and inertinite contents in durite, trimacerite and carbargilite (see Supplementary material, point 6, Figs VII-X) implies a more intensive decomposition of the organic matter in an arid and oxidizing environment. The ranges of the selected plant species in the Central and Western Bohemian Basins are reported by Pešek (2004) and Opluštil et al. (2016); the plants are described by Kvaček and Straková (1997) and Turek et al. (1998). Intensive degradation of vegetation and decomposition of organic matter under given sedimentation conditions suggests a relatively easy conversion of organic matter to coal, but there is nothing to indicate high temperatures during conversion.

Since clay minerals were found with K5 (3 vol.\%) and K6 (11 vol.\%) samples, X-ray analysis was performed for their further characterization. Kaolinite, dickite, muscovite and palygorskite were identified, which corresponds to Pešek and Sýkorová (2006) findings.

\subsubsection{Thermally and oxidatively altered samples with mylonite structures and microbreccia}

In the last series of samples, K8-K11, a micropetrographic analysis of the coal from the contact with a carbonate vein is performed. The mineralized banded coal examined (Fig. 7) is characterized by a horizontal, grey tuffitic layer, which was, like the actual coal layer, intersected by a diagonal calcite vein. Attention was paid to the coal strongly disrupted by numerous cracks filled up by calcite.

The bands of collotelinite (Fig. 8) with calcite vein occur quite often. There also occurs inertinite, frequently fragmented fusinite, semifusinite, macrinite and inertodetrinite. The macerals of the inertinite group are dominated by fusinite with inertodetrinite and macrinite (Table 3 ). Lipnite macerals are dominated by sporinite and resinite (Table 3) with a different intensity of yellow fluorescence color. An interesting feature is the occurrence of finegrained detritus of the size of the liptodetrinite and bituminite particles with the optical properties of resinite, dispersed in vitrinite. The coal mass is interwoven with a relatively dense network of calcite veinlets of varying widths and lengths. Significant shifts of the layers and

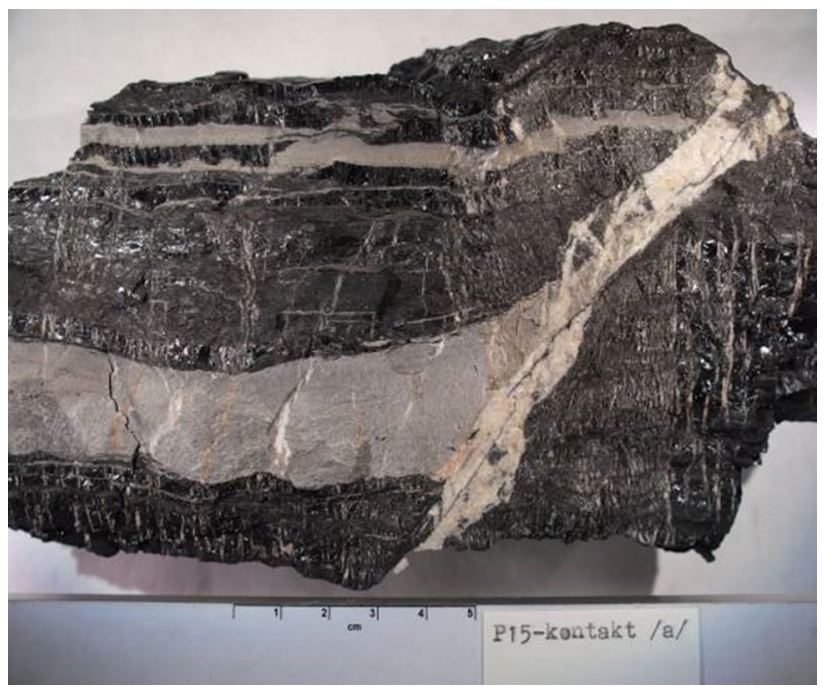

Fig. 7 Banded coal with a horizontal grey tuffitic layer and a diagonal calcite vein 


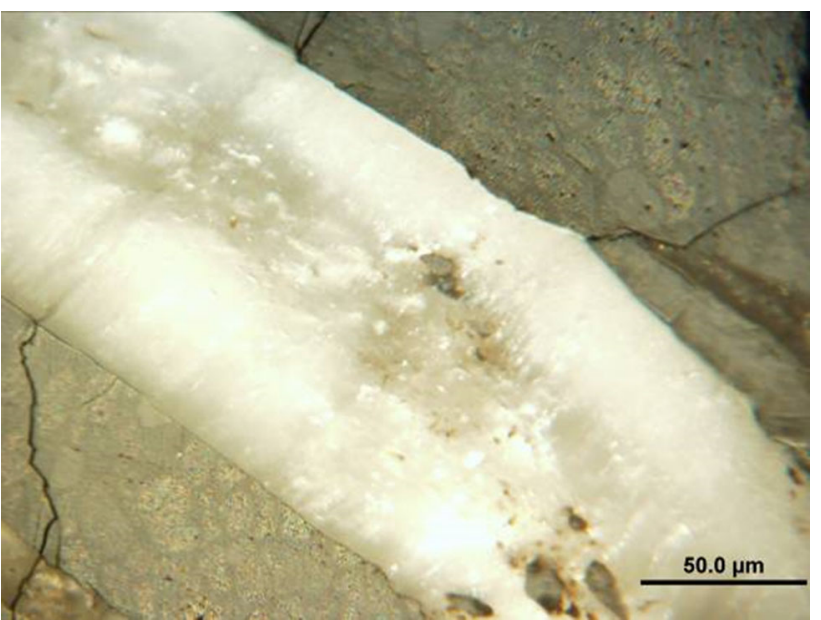

Fig. 8 Collotelinite with calcite vein

structures similar to mylonite or microbreccias (Figs. 9 and 10) are observed. Such structures are generally known as manifestations of microtectonics and thermal oxidative alteration.

Some mylonite structures of collotelinite show the reflectance $R_{r}$ as higher than the average (see Table 2)mostly above $0.75 \%$ (Fig. 11); the more reflective mylonite structures of low altered collotelinite with a reflectance $R_{r}$ of $0.82 \%$ (Fig. 12) occur quite often. Such structures are typical for tectonically and thermally-oxidatively affected coal. Further, smaller dispersed collotelinite fragments, scattered fine-grained resinite and fusinite fragments, vitrinite and inertinite particles and the carbonate mass containing their dispersed crushed pieces were observed. It is evident that the penetration of calcite significantly affected the coal, which led to its rupture and the shift of its individual parts (Fig. 13), or to the rupture of the coal and the filling of the space created. Besides, numerous structures of

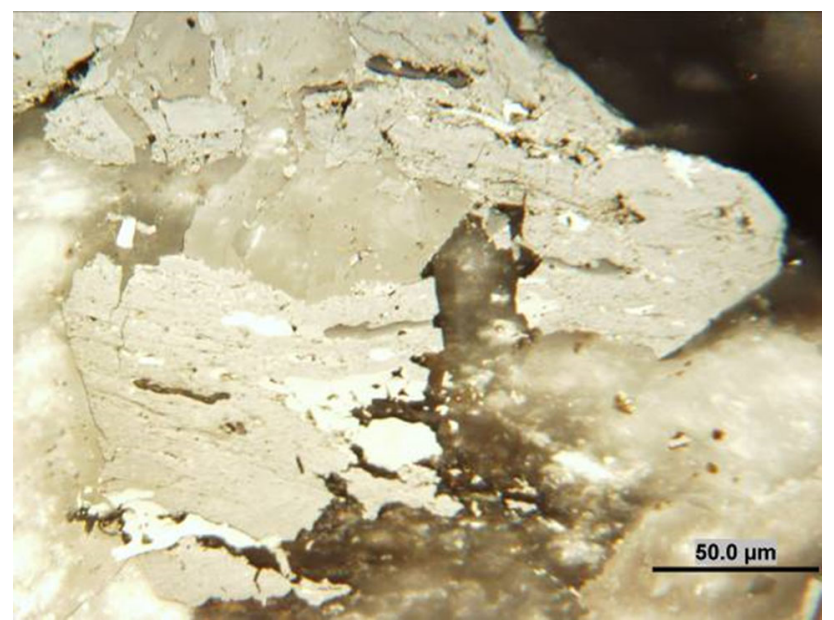

Fig. 9 Vitrinite with dispersed inertinite and liptinite macerals faulted by calcite

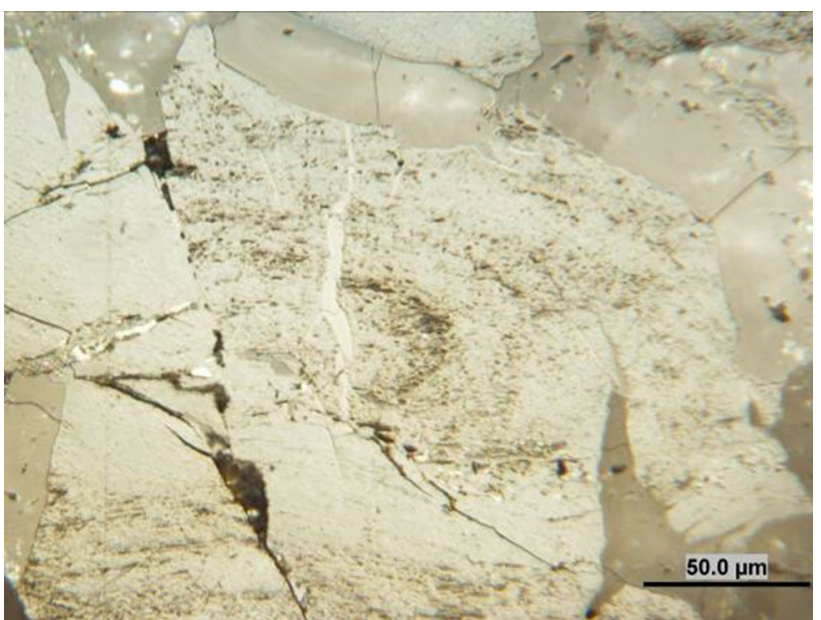

Fig. 10 Vitrinite with finely dispersed sporinite, resinite, liptodetrinite and bituminite, faulted by cracks

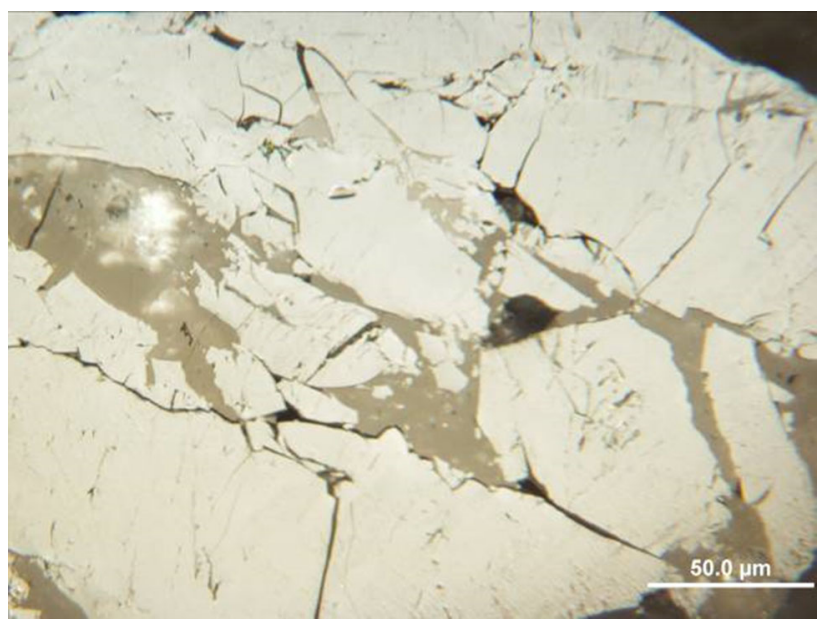

Fig. 11 Mylonite structure of low altered collotelinite $\left(R_{r}\right.$ above $0.75 \%)$

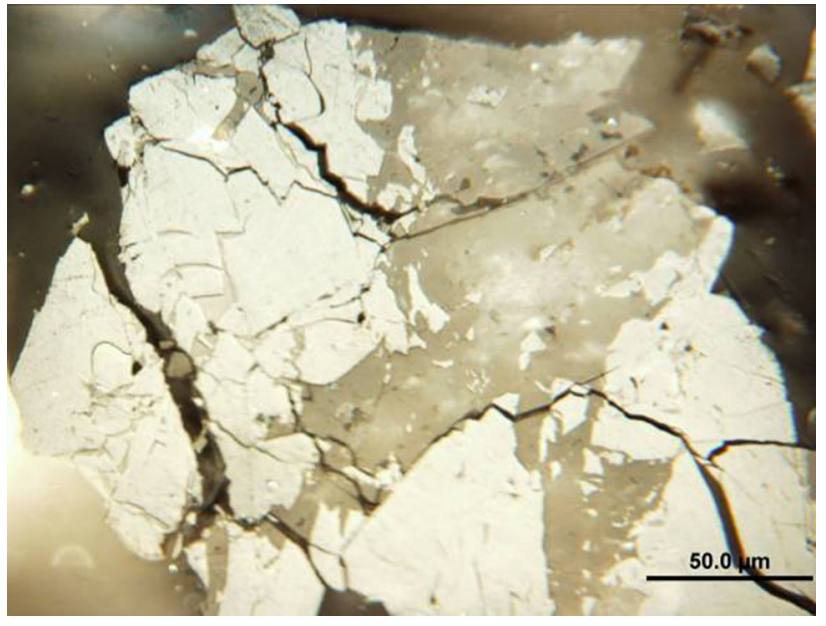

Fig. 12 A mylonite structure of low altered collotelinite $\left(R_{r}=0.82 \%\right)$ 


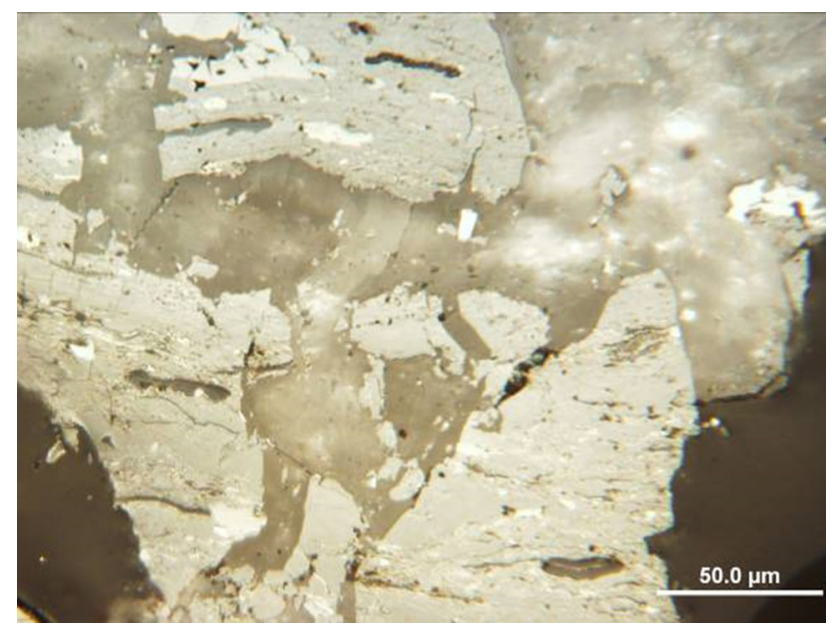

Fig. 13 Vitrinite with dispersed macerals of liptinite and inertinite faulted by calcite

mylonite, microbreccia with a reflectance $R_{r}$ of $0.85 \%$ (Fig. 14) are obvious.

The last series of studied samples exhibited a greater failure of the coal. It reveals that:

(1) the deeper penetration of carbonate disrupted the coal layers and led to the formation of cracks of various sizes and their relatively dense network filled with calcite and with coal fragments and

(2) the breaking of the coal into individual grains and the formation of mylonite structures as well as the formation of microbreccia occurred, which are typical manifestations of microtectonics and thermal oxidative alteration. These manifestations were most frequently observed in the case of collotelinite, whose reflectance was higher than the average reflectance, specifically $0.75 \%-0.85 \%$.

In summary, the micropetrographic analysis of the studied coal samples from the Kladno-Rakovník Basin

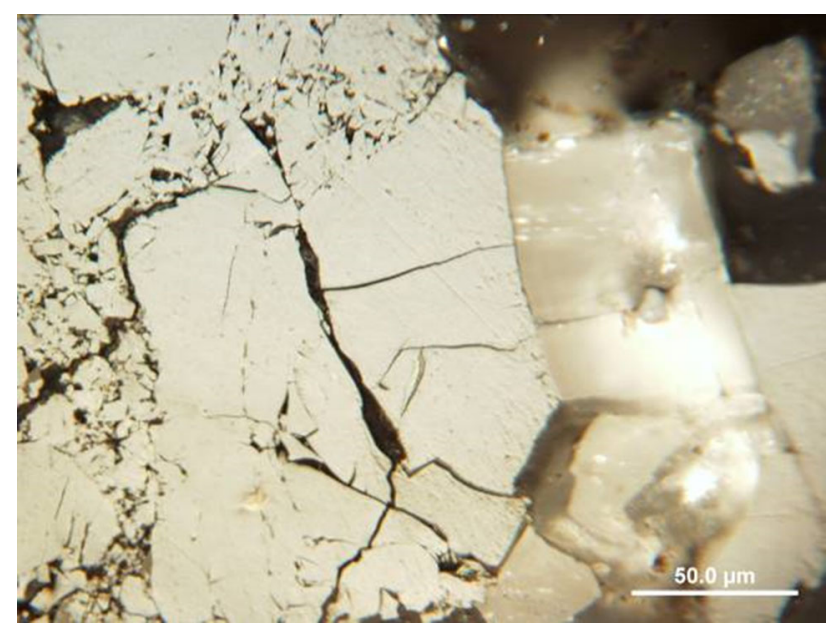

Fig. 14 Low altered collotelinite and vitrodetrinite with microbreccia $\left(R_{r}=0.85 \%\right)$ revealed the low thermal and oxidative alteration corresponding to rather lower temperatures. The reflectance $R_{r}$ of the samples studied was $0.65 \%-0.69 \%$, which corresponds well to those determined for the coal of the KladnoRakovník Basin by Pešek and Sýkorová (2006), $R_{r}$ $=0.60 \%-0.75 \%$, also involving altered samples. Regarding the microthermometric measurements of fluid inclusions (Zachariáš and Pešek 2011), coal was altered at temperatures corresponding to the temperatures of carbonate fluids; at these temperatures, mylonite and microbreccia phenomena occurred. These microtectonics phenomena are probably of hydrothermal origin and were generated by the thermally driven circulation of fluids in the vicinity of an intrusive from an obscured volcanic center. As a result, the thermally and oxidatively altered coal was formed, because a higher porosity of coal occurred allowing the transport of oxygen through the pores and the reaction of $\mathrm{O}_{2}$ with active sites on the pore surfaces. Subsequently, after fluid cooling, crystallization and the formation of the observed carbonate veins and veinlets occurred. These veins and veinlets could have formed after maximum burial.

\subsection{Temperature of coalification}

\subsubsection{Temperature of coalification as estimated from $R_{r}$ values}

For a preliminary assessment of the coalification temperature, a statistical dependence showing the correlation between $R_{r}$ and the maximum burial temperature $\left(t_{\max }\right)$ was used $\left(\ln R_{r}=0.0078 t_{\max }-1.2\right.$, Barker and Pawlewicz 1986). From the $R_{r}$ values for samples K1-K3 (0.66-0.68, Table 3) and those reported by Pešek and Sýkorová (2006) for the Kladno-Rakovník Basin, Upper Radnice Coal Seam (on average 0.67 , often 0.65 ), a temperature of $\sim 100{ }^{\circ} \mathrm{C}$ results, if we consider the value of 0.65 , then $98^{\circ} \mathrm{C}$. However, due to the statistic character of the dependence, this needs to be further specified.

\subsubsection{Temperature of coalification as estimated from the ${ }^{27} \mathrm{Al}$ MAS NMR spectral analysis}

Al complexes with organic ligands are integral part of initial organic matter as well as the organic mass of resulting coal (Bouška 1981; Bouška et al. 2000). In coal organic mass, the $\mathrm{Al}$ complex molecule contains either 2 phenoxide ions $\mathrm{C}_{6} \mathrm{H}_{5} \mathrm{O}^{-}, 3$ water molecules and 1 hydroxide ion $\mathrm{OH}^{-}$(triaquo-hydroxo-diphenoxido-aluminum(III) complex, THDA, $\left.\mathrm{Al}\left(\mathrm{H}_{2} \mathrm{O}\right)_{3}(\mathrm{OH})\left(\mathrm{C}_{6} \mathrm{H}_{5} \mathrm{O}\right)_{2}\right)$ or 3 phenoxide ions and 3 water molecules (triaquo-triphenoxido-aluminum(III) complex, TTA, $\left.\mathrm{Al}\left(\mathrm{H}_{2} \mathrm{O}\right)_{3}\left(\mathrm{C}_{6} \mathrm{H}_{5} \mathrm{O}\right)_{3}\right)$, 
while Al is hexa-coordinated with O (Straka, 2016) (see Supplementary material, point 1, Figs. I and II).

The use of the ${ }^{27} \mathrm{Al}$ MAS NMR analysis is based on the fact that the complexes of hexa-coordinated $\mathrm{Al}$ with organic ligands are thermally unstable and decomposed at temperatures of $90-95{ }^{\circ} \mathrm{C}$ (Straka 2016), which results in the transition from hexa- to tetra-coordinated $\mathrm{Al}$ (with $\mathrm{O}$ ). This change is reflected in peak shifts in the ${ }^{27} \mathrm{Al}$ MAS NMR spectra. If a coal sample contains only a complex with hexa-coordinated $\mathrm{Al}$, the spectrum contains only one peak at 3.4-4 ppm (in the case of THDA) or at 14-15 ppm (in the case of TTA); simultaneously it means that the concerned coal was not altered. However, if the sample contains a structure with $\mathrm{Al}$ tetra-coordinated with $\mathrm{O}$, the presence of tetra-coordinated $\mathrm{Al}$ is manifested in the spectrum by the peak shift at 60-70 ppm (Duxson 2007) with a significant maximum (Hanzlíček and Perná 2011); simultaneously it means that the concerned coal is oxidative and thermally altered.

With unaltered samples K1 and K2, identification of the Al complexes with organic ligands using the ${ }^{27} \mathrm{Al}$ MAS NMR method was carried out with the aim to determine the maximum temperature of coalification. (Main features of the samples tested: sample $\mathrm{K} 1$ had a mineral content of $4.4 \mathrm{vol} . \%$ of calcite (Table 3), no clay minerals were found by XRD; the collotelinite content was of 59.3 vol.\% (Table 3). Sample K2 had a mineral content of 9 vol.\% of calcite and $\sim 1$ vol.\% of pyrite (see Sect. 4.2.2), no clay minerals were found by XRD; the collotelinite content was 44.8 vol.\% (Table 3). Both these samples had 1 wt. $\%$ of $\mathrm{Al}$, as X-ray fluorescence spectrometry measurements proved.) The obtained ${ }^{27} \mathrm{Al}$ MAS NMR spectra showed the presence of hexa-coordinated $\mathrm{Al}$, specifically the triaquohydroxo-diphenoxido-aluminum(III) complex (THDA, see Supplementary material, point 1 , Fig. I), which was identified in the coal organic mass by a peak shift at $4.15 \mathrm{ppm}$ (Figs. 15 and 16).

As mentioned, this identified complex is not thermally stable and begins to decompose at a temperature of $90-95{ }^{\circ} \mathrm{C}$, as proven by its thermogravimetric curve

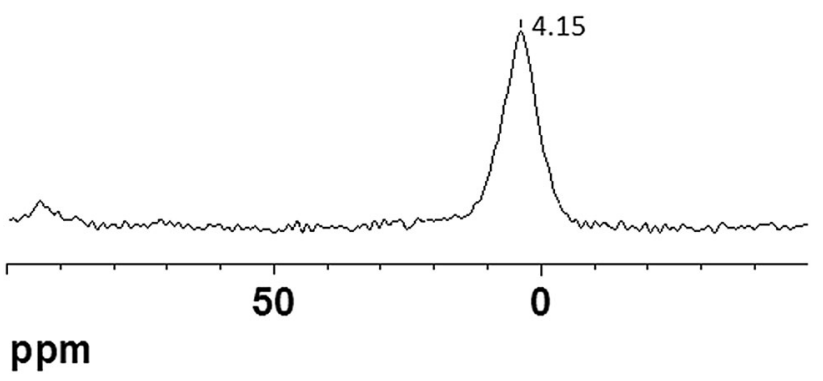

Fig. 15 The ${ }^{27} \mathrm{Al}$ MAS NMR spectrum of the unaltered sample K1 $(11 \mathrm{kHz}, \mathrm{RT})$. The peak at $4.15 \mathrm{ppm}$ corresponds to the THDA complex

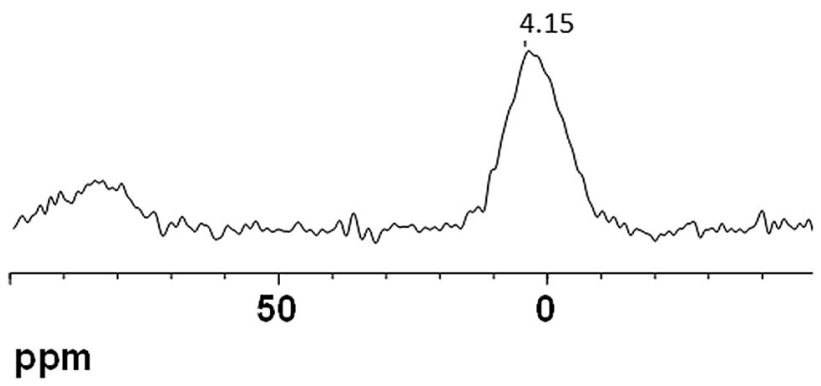

Fig. 16 The ${ }^{27} \mathrm{~A} 1$ MAS NMR spectrum of the unaltered sample K2 $(11 \mathrm{kHz}, \mathrm{RT})$. The peak at $4.15 \mathrm{ppm}$ corresponds to the THDA complex

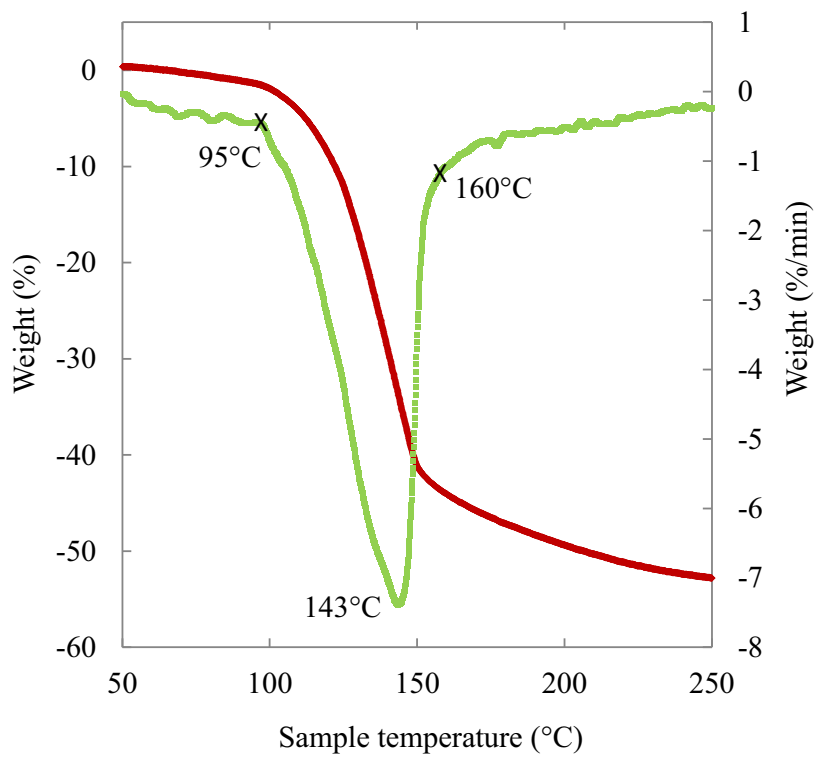

Fig. 17 The TG (red line) and DTG (green line) curves of the THDA complex

(Fig. 17). As the peak shift at $60-70 \mathrm{ppm}$ with significant maximum was not recorded in the spectra of tested samples (Figs. 15 and 16), the presence of tetra-coordinated $\mathrm{Al}$ can be excluded.

So, the proven presence of hexa-coordinated $\mathrm{Al}$ and simultaneously the absence of tetra-coordinated $\mathrm{Al}$ in the coal organic mass indicates that temperature of the complex decomposition was not reached during the formation of the investigated coal. Therefore, the maximum coalification temperature was lower than $90-95^{\circ} \mathrm{C}$ and the maximum burial temperature can be considered as lower than $90{ }^{\circ} \mathrm{C}$.

\subsubsection{Temperature of coalification as estimated from $\delta^{13} \mathrm{C}$ values}

As a further argument for the considered low temperature coalification, the $\delta^{13} \mathrm{C}$ values and thermal stability of whewellite were taken into account. The reason is that 
whewellite (calcium oxalate monohydrate, $\mathrm{CaC}_{2} \mathrm{O}_{4} \cdot \mathrm{H}_{2} \mathrm{O}$ ), which has been found for a long time in the pelosiderite concretions from the Kladno-Rakovník Basin, Upper Radnice Coal Seam, is thermally stable up to $68^{\circ} \mathrm{C}$ (Hofmann and Bernasconi 1998), moreover, the temperature of its formation can be estimated from the $\delta^{13} \mathrm{C}$ values. In this case, the $\delta^{13} \mathrm{C}$ values for whewellite from the pelosiderite concretions are significantly higher than usual, specifically (+ 3.2)-(+ 14.7)\%o (Žák and Skála 1993), and are similar to those for whewellite from comparable concretions from Hoheneggelsen, Germany $\left(\delta^{13} \mathrm{C}+7.8\right.$ and $+8.7 \%$, diagenetic occurrence, Hoefs, 1969; Hofmann and Bernasconi, 1998). (It is important to note that the normal range of $\delta^{13} \mathrm{C}$ values is $(-29.3)$ to $(-27.8) \%$ for organic matter (Hoefs 1969) or (-23.4) to $(-23.2) \%$ for sedimentary organic matter (Chernykh and Piloyan 1971)). This implies the influence of microorganism enzymes on the ratio of isotopes ${ }^{13} \mathrm{C} /{ }^{12} \mathrm{C}$ in calcium oxalate monohydrate, produced during an anaerobic degradation of organic matter. The most frequent finds of calcium oxalate monohydrate crystals come precisely from the mentioned pelosiderite concretions formed during early diagenesis.

Whewellite is a rare mineral occurring in the cracks of carbonate concretions in argillaceous rocks of sedimentary basins rich in organic matter, especially in those containing coal. Whewellite formation in such an environment is related to the mobilization and crystallization of calcium oxalate monohydrate formed during the decomposition of organic matter in the early stage of diagenesis (Bernard et al. 1981). Hoefs (1969) first reported the unusual high carbon isotopic ratio of whewellite from carbonate concretions as $\delta^{13} \mathrm{C}+8.6 \%$ (vs. PDB standard) and considered a bacterial process in the formation of whewellite as one possibility. Usually, carbonate concretions show high $\delta^{13} \mathrm{C}$ values in the center of the concretion, which is associated with the incorporation of $\mathrm{CO}_{2}$ produced by the action of microbial enzymes on organic matter (fermentation) in the early diagenetic stage, and lower $\delta^{13} \mathrm{C}$ values in the peripheral parts of concretion, which is associated mainly with thermal decarboxylation during deeper burial in the later diagenetic (abiotic) stage. The same was found with the basal siderite matrix of the pelosiderite concretions hosting whewellite crystals in the Kladno-Rakovník Basin, Upper Radnice Coal Seam. With carbonate precipitates in the center, high values $\delta^{13} \mathrm{C}$ up to $+11.9 \%$ were found, resulting from the incorporation of $\mathrm{CO}_{2}$ produced during the fermentation of the organic acids in the early diagenetic stage, while the peripheral parts of the concretions showed lower $\delta^{13} \mathrm{C}$ values $(+3.7-(-6.9) \%)$, often slightly negative ones, resulting from the thermal decarboxylation of the remaining organic acids in the later diagenesis. The mentioned values well correspond to the other literature data concerning high $\delta^{13} \mathrm{C}$ values (Whiticar 1996).

The process can be described in such a way that in the early diagenetic stage, an aerobic degradation of the accumulated organic matter generated large amounts of organic acids; due to the weakly acidic environment, no precipitation of carbonates was there. After depletion of the aerobic oxidation potential, the formed organic acids served as a substrate for fermentation by enzymes of anaerobic bacteria; this fermentation had to take place at temperatures below $50{ }^{\circ} \mathrm{C}$. Organic acids contained both ${ }^{12} \mathrm{C}$ and ${ }^{13} \mathrm{C}$, but those with isotopically lighter ${ }^{12} \mathrm{C}$ were consumed by bacteria first and $\mathrm{CO}_{2}$ with ${ }^{12} \mathrm{C}$ was released. Due to this, organic acids with ${ }^{13} \mathrm{C}$ were concentrated in the organic matter. Simultaneously, the $\mathrm{pH}$ of the environment increased and carbonates and calcium oxalate monohydrate with ${ }^{13} \mathrm{C}$ were formed. Subsequently, the basal siderite matrix of the pelosiderite concretions was created and, in cracks of these concretions, ankerite and whewellite precipitated and crystallized. In the later diagenetic stage, during deeper burial, the remaining organic acids with a lower content of ${ }^{13} \mathrm{C}$ (and lower $\delta^{13} \mathrm{C}$ values) were thermally decarboxylated and formed carbonates with lower $\delta^{13} \mathrm{C}$ values crystallized in the peripheral parts of concretions. This crystallization took place at temperatures below $50{ }^{\circ} \mathrm{C}$.

From the mentioned data, Pešek and Zachariáš (2011) concluded that carbonate concretions were formed at temperatures below $50{ }^{\circ} \mathrm{C}$. This is reasonable because the mentioned enzymatic reactions and crystallizations had to be conducted at relatively low temperatures. And also, it is important that whewellite is thermally stable up to $68^{\circ} \mathrm{C}$. This implies that the coalification of the Kladno-Rakovník Basin occurred at significantly lower temperature than previously estimated temperature (below $\sim 70{ }^{\circ} \mathrm{C}$ ). So, the maximum burial temperature can be finally considered as $\sim 70^{\circ} \mathrm{C}$.

\subsection{Temperature of coal alteration}

\subsubsection{Temperature of coal alteration as estimated from microthermomery data}

At present, microthermometry represents a standard technique for the estimation of the temperatures of fluids, however, so far it has been rarely used in the study of coalbearing basins. Fortunately, this method was recently employed in the study of carbonate-dominated veins/ veinlets from some coal seams of the Central and West Bohemian basins including Kladno-Rakovník Basin, Radnice member, Upper Radnice Coal Seam. Therefore, for the considered low temperature coal alteration, the mentioned microthermomery data obtained by Zachariás 
and Pešek (2011) and following fluid inclusion analysis were taken into account. In this case, in calcite veins, inclusions of the two-phase liquid-rich type were investigated. It was found that they homogenized to the liquid state mostly at $50-80{ }^{\circ} \mathrm{C}$. If the fluid temperatures obtained in this way are considered, a value of the paleogeothermal gradient of $40{ }^{\circ} \mathrm{C} / \mathrm{km}$ (determined from depth-temperature relationship) is obtained. However, the actual fluid temperatures were probably higher by $\sim 10-20{ }^{\circ} \mathrm{C}$ because of pressure corrections, of $60-90$ or $70-100{ }^{\circ} \mathrm{C}$.

The measured total homogenization temperature was considered more or less the same as the actual fluid temperature, and the fluid pressure as significantly lower than the fully hydrostatic load. (Because of sediment thickness is less than $2 \mathrm{~km}$ in our case, hydrostatic, not lithostatic pressure was considered.) Under these assumptions, it seems to be reasonable to correct the found total homogenization temperature by $10-20{ }^{\circ} \mathrm{C}$, as mentioned. If the measured temperature was $91.0 \pm 2.0^{\circ} \mathrm{C}$, then the corrected value can be considered as $\sim 100-113{ }^{\circ} \mathrm{C}$. With a temperature of $113{ }^{\circ} \mathrm{C}$, the paleogeothermal gradient is $45^{\circ} \mathrm{C} /$ $\mathrm{km}$, which corresponds well to that found by (Šafanda et al. 1990), see above. So, the formation of thermally and oxidatively altered coal occurred through the activity of hydrothermal fluids at a temperature of $\sim 113{ }^{\circ} \mathrm{C}$; most likely, the alteration took place after the maximum burial.

\subsubsection{Temperature of coal alteration as estimated from micropetrographic data}

The above-mentioned micropetrographic observations suggest that the formed coal underwent thermal and oxidative alteration. This alteration was probably caused by hot hydrothermal fluids. During the alteration, a higher porosity of coal occurred (Fig. 18) allowing the transport of oxygen through the pores and the reaction of $\mathrm{O}_{2}$ with pore surfaces.

As altered coal always shows higher porosity than unaltered coal, it can be deduced that during alteration, the porous texture with a higher porosity and larger pore volume evolved, analogously (Shi et al. 2018). The larger average pore diameter is attributed to this newly formed porous system as a main factor influencing the subsequent diffusion of oxygen into the coal structure and the consumption of oxygen during this low-temperature oxidation (Meng et al. 2016). The newly created porous system increased the accessibility of oxygen from aqueous hot fluids to active sites on the pore surfaces in coal and allowed the oxidation of the coal mass; due to this, oxidative alteration occurred.

According to Meng et al. (2016), the effective diffusion coefficient of oxygen into the porous texture of thermally altered coal is linearly dependent on the average pore

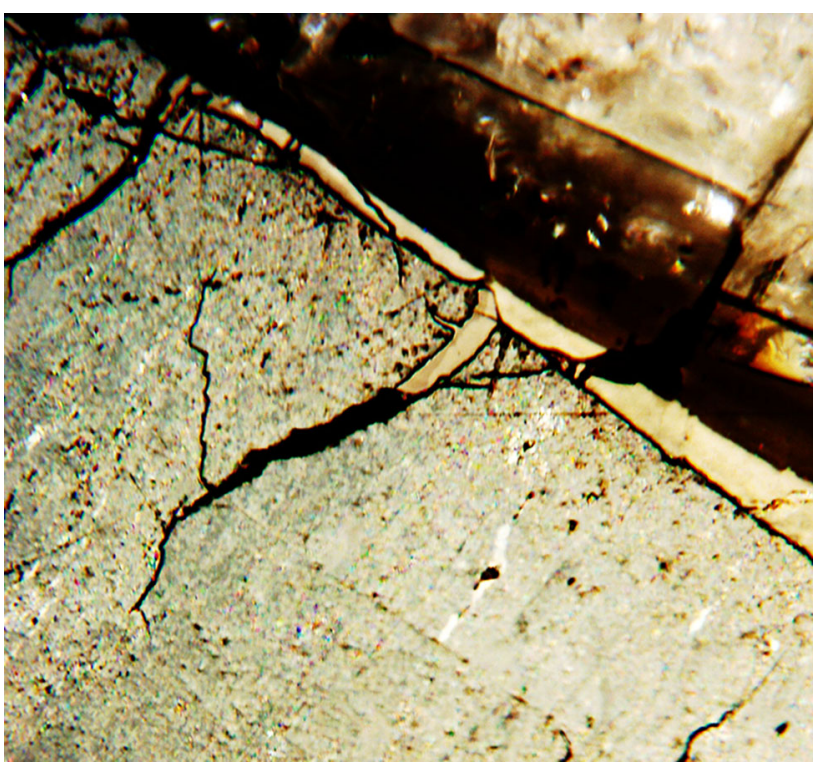

Fig. 18 Porous texture of altered coal from the Kladno mine, Kladno-Rakovník Basin. Contact of carbonate with collotellinite faulted by cracks

diameter, while the fractal dimension of the porous system is included. If the average diameter increases, the effective diffusion coefficient also increases, while the average diameter affects the coal-oxygen diffusion more significantly than the fractal dimension. Therefore, in this case, the heating of coal up to $\sim 100 / 113{ }^{\circ} \mathrm{C}$ improved the transport capacity of the oxygen in the pores and the reaction of $\mathrm{O}_{2}$ with active sites on the pore surfaces occurred. The works of Meng et al. (2016), Su et al. (2017) and Shi et al. (2018) reveals that with increase of coal temperature, consumption of oxygen grew slowly at first at temperatures up to $70{ }^{\circ} \mathrm{C}$ while $\mathrm{O}_{2}$ chemisorption dominated, then, at temperatures above $80{ }^{\circ} \mathrm{C}$, it grew rapidly as $\mathrm{O}_{2}$ reaction with active sites dominated. The actual oxygen reaction took place on the active centers of the coal structure, namely on the aliphatic and alicyclic groups associated with the aromatic rings, to form unstable peroxides and hydroperoxides (Kurková 2002); from these unstable intermediates then stable oxygen compounds with $\mathrm{CO}$ and $\mathrm{COO}$ groups are formed; and finally, retrograde humic acids are formed (Klika and Kraussová 1993; Klika 1999; Kurková 2002). Thus, the increase in the oxygen content (Table 2) is mainly due to the increase in the retrograde humic acids amount.

\section{Conclusions}

The temperatures of coalification and thermal and oxidative alteration of coal from the Kladno-Rakovník Basin, part of the Late Paleozoic continental deposits of the Czech 
Republic, were established. The coalification temperature was assessed using three independent methods, (a) micropetrographic observations of unaltered coal, (b) a ${ }^{27} \mathrm{Al}$ MAS NMR spectra analysis of the Al complexes with organic ligands present in the coal organic mass, which are an integral part of organic matter as well as the resulting coal, (c) evaluations of the $\delta^{13} \mathrm{C}$ values and the thermal stability of whewellite (calcium oxalate monohydrate, $\mathrm{CaC}_{2} \mathrm{O}_{4} \cdot \mathrm{H}_{2} \mathrm{O}$ ) occurred in pelosiderite concretions from the Kladno-Rakovník Basin, Upper Radnice Coal Seam. The temperature of the coal alteration was assessed using both micropetrographic observations and fluid inclusions data analysis.

Micropetrographic observations of the unaltered samples showed no evidence of coalification at high temperatures. Further, the ${ }^{27} \mathrm{Al}$ MAS NMR spectra of the selected coal samples proved the presence of the triaquo-hydroxodiphenoxido-aluminum(III) complex, which was identified in the coal organic mass. The identified complex with hexa-coordinated $\mathrm{Al}$ (to oxygen) is not thermally stable and begins to decompose at a temperature of $90-95{ }^{\circ} \mathrm{C}$, as proven by its thermogravimetric curve. The presence of the hexa-coordinated $\mathrm{Al}$ and simultaneously the absence of tetra-coordinated $\mathrm{Al}$ in the examined samples therefore mean that a temperature of $\sim 90{ }^{\circ} \mathrm{C}$ was not reached during the coalification. Further, regarding the very high $\delta^{13} \mathrm{C}$ values of whewellite in the pelosiderite concretions from the Kladno-Rakovník Basin, Upper Radnice Coal Seam, specifically $(+3.2)-(+14.7) \%$, and thermal stability of whewellite up to $68{ }^{\circ} \mathrm{C}$, the temperature of $\sim 70{ }^{\circ} \mathrm{C}$ as maximum burial temperature was suggested.

Micropetrographic observations of the altered coal showed a weaker intensity of fluorescence of the liptinites and the formation of mylonitic structure as well as microbreccia. These phenomena are typical for the thermal and oxidative alteration of coal and were observed frequently in collotelinite, whose reflectance was higher than the average reflectance $\left(R_{r} \quad 0.66 \%-0.69 \%\right)$, specifically $0.74 \%-0.86 \%$. Therefore, the altered coal was evaluated as low thermally and oxidatively altered. In accordance with the fluid inclusion data analysis indicating the temperatures of the acting fluids as $\sim 100-113^{\circ} \mathrm{C}$, the alteration temperature was suggested as $\sim 113{ }^{\circ} \mathrm{C}$. During alteration, a higher porosity of coal occurred facilitating the transport of oxygen through the pores and the reaction of $\mathrm{O}_{2}$ with the pore surfaces. The carbonate-dominated veins and veinlets were generated by thermally driven circulation of hot fluids in the vicinity of intrusives from obscured volcanic center, and were formed after maximum burial.

Acknowledgement This work was carried out thanks to the support of the Long-Term Project for the Conceptual Development of the Research Organization No. RVO 67985891. The authors thank Prof.
Jiří Pešek, Faculty of Sciences, Charles University in Prague, for the valuable assistance in selecting the samples and consultations.

Open Access This article is distributed under the terms of the Creative Commons Attribution 4.0 International License (http://crea tivecommons.org/licenses/by/4.0/), which permits unrestricted use, distribution, and reproduction in any medium, provided you give appropriate credit to the original author(s) and the source, provide a link to the Creative Commons license, and indicate if changes were made.

\section{References}

Barker Ch. E (1989) Temperature and time in the thermal maturation of sedimentary organic matter. In: Naeser ND, McCulloh TH (eds) Thermal history of sedimentary basins. Springer, New York, pp 75-98

Barker Ch. E, Pawlewicz MJ (1986) The correlation of vitrinite reflectance with maximum temperature in humic organic matter. In: Buntebarth G, Stegena L (eds) Paleogeothermics: evaluation of geothermal conditions in the geological past. Lecture Notes in Earth Sciences, vol. 5, pp 79-93

Basu P (2010) Biomass Gasification and Pyrolysis: Practical Design and Theory. Academic Press, Burlington, pp 1-365

Bernard JH et al (1981) Mineralogy of Czechoslovakia. Academia, Prague

Botor D, Littke R (2003) 2-D numerical modelling of the burial and thermal history of Carboniferous strata in the Lublin coal basin, in: XXVI Sympozjum Geologia formacii wenglonosnych Polski, Materialy Akademia Górniczo-Hutnicza w Krakowie, May 9-10, Kraków, pp. 9-14

Bouška V (1981) Geochemistry of coal. Coal science and technology. Elsevier, Amsterdam, pp 1-284

Bouška V, Pešek J, Sýkorová I (2000) Probable modes of occurrence of chemical elements in coal. Acta Montana, Series A 10(117):53-90

Burchil P, Howarth OW, Sword BJ (1991) MAS n.m.r. studies of inorganic elements in coal and combustion residues. Fuel 70:361-366

Chernykh IV, Piloyan GO (1971) Whewellite in hydrothermal uranium deposit. Dokl. Akad. Nauk S.S.S.R. 201:1449-1452

Copard Y, Disnar RJ, Becq-Giraudon JF, Boussafir M (2000) Evidence and effects of fluid circulation on organic matter in intramontane coalfields. Int J Coal Geol 44:49-68

Daněk V, Pešek J, Valterová P (2002) Coal clasts in the Bolsovian (Westphalian C) sequence of the Kladno-Rakovník continental basin (Czech Republic): implication of the timing of maturation. Polish Geological Institute Special Paper 7:36-78

Daniels EJ, Aronson JL, Altaner SP, Clauer N (1994) Late Permian age of NH-bearing illite in anthracite from Eastern Pennsylvanian-temporal limits on coalification in the Central Appalachians. Geol Soc Am Bull 7:760-766

Demirbas A (2009) Biofuels: securing the planet's future energy needs, 1st edn. Springer, London, pp 1-336

Duxson P, Fernández-Jimenéz A, Provis JL, Lukey GC, Palomo A, van Deventer JSJ (2007) Geopolymer technology: the current state of the art. J Mater Sci 42:2917-2933

Freitas JCC, Schettino MA Jr, Emmerich FG, Wong A, Smith ME (2007) A multiple-Field ${ }^{23} \mathrm{Na}$ NMR study of sodium species in porous carbons. Solid State Nucl Magn Reson 32:109-117

Gayer RA, Pešek J, Sýkorová I, Valterová P (1996) Coal clasts in the upper Westphalian sequence of the South Wales coal basin: implications for the timing of maturation and fracture 
permeability. In: Gayer R, Harris J (Eds.), Coalbed methane and coal geology, Geological Society Special Publication 109: $103-130$

Geršlová E, Goldbach M, Geršl M, Skupien P (2016) Heat flow evolution, subsidence and erosion in Upper Silesian Coal Basin, Czech Republic. Int J Coal Geol 154-155:30-42

Given PH (1988) The origin of coals. In: Yuzum Y (ed) New trends in coal science. Kluwer Academic Publishers, Dordrecht, pp 1-52

Golab AN, Carr PF (2004) Changes in geochemistry and mineralogy of thermally altered coal, Upper Hunter Valley, Australia. Int J Coal Geol 57:197-210

Golab AN, Hutton AC, French D (2007) Petrography, carbonate mineralogy and geochemistry of thermally altered coal in Permian coal measures, Hunter Valley, Australia. Int J Coal Geol 70:150-165

Hanzlíček T, Perná I (2011) The aluminum-silicates in stabilization processes in fluidized-bed ash. Ceramics-Silikáty 55:94-99

Hertle M, Littke R (2000) Coalification pattern and thermal modelling of the Permo-Carboniferous Saar basin (SW-Germany). Int J Coal Geol 44:273-296

Hoefs J (1969) Natural calcium oxalate with heavy carbon. Nature 223(5204):396

Hofmann BA, Bernasconi SM (1998) Review of occurrences and carbon isotope geochemistry of oxalate minerals: implications for the origin and fate of oxalate in diagenetic and hydrothermal fluids. Chem Geol 149:127-146

Hosoya T, Kawamoto H, Saka S (2009) Solid/liquid- and vapor-phase interactions between cellulose- and lignin-derived pyrolysis products. J Anal Appl Pyrol 85:237-246

Howarth OW, Ratcliffe GS, Burchill P (1987) Solid-state nuclear magnetic resonance studies of sodium and aluminium in coal. Fuel 66:34-39

Hower JC, Gayer RA (2002) Mechanism of coal metamorphism: case studies from Paleozoic coalfields. Int J Coal Geol 50:215-245

$\mathrm{Ht} \mathrm{Su}, \mathrm{Fb}$ Zhou, Js Li, Hn Qi (2017) Effects of oxygen supply on lowtemperature oxidation of coal: a case study of Jurassic coal in Yima. China, Fuel 202:446-454

ICCP (1998) The new vitrinite classification (ICCP system 1994). Fuel 77:349-358

ICCP (2001) The new vitrinite classification (ICCP system, 1994). Fuel 80:459-471

ISO 7404-5 (2009) Methods for the petrographic analysis of coals, Part 5: Method of determining microscopically the reflectance of vitrinite

ISO 7404-3 (2009) Methods for the petrographic analysis of coals, Part 3: Method of determining maceral group composition

Kanehashi K, Saito K (2004) First application of ${ }^{27} \mathrm{Al}$ multiple quantum magic angle spinning nuclear magnetic resonance at 16.4 $\mathrm{T}$ to inorganic matter in natural coals. Energy Fuels 18:1732-1737

Kirkpatrick RJ (1988) MAS NMR spectroscopy of minerals and glasses. In: Hawthorne FC (ed) Spectroscopic methods in mineralogy and geology, reviews in mineralogy series, vol 18 . Mineralogical Society of America, Washington DC

Klika Z (1999) Oxidative altered coal from the Upper Silesian Coal Basin. J Czech Geol Soc 44(3-4):335-342

Klika Z, Krausová J (1993) Properties of altered coals associated with Carboniferous red beds in the Upper Silesian Coal basin and their tentative classification. Int J Coal Geol 22:217-235

Klika Z, Osovský M (1999) Thermally altered coal from Upper Silesian Coal Basin. J Czech Geol Soc 44(3-4):343-352

Kurková M. (2002) Oxidative and Thermally Altered Coals from Red Bed Bodies Region of the Upper Silesian Coal Basin. PhD Thesis, VŠB-Technical University of Ostrava, Czech Rep
Kus J (2017) Oxidatively and thermally altered high-volatile bituminous coals in high-temperature coal fire zone No. 8 of the Wuda Coalfield (North China). Int J Coal Geol 176-177:8-35

Kvaček J., Straková M. (1997) Catalogue of Fossil Plants Described in Works of Kaspar M. Sternberg. National Museum, Prague 1997, pp. 1-202, 67 plates

Landais P, Gérard L (1996) Coalification stages from confined pyrolysis of an immature humic coal. Int $\mathrm{J}$ Coal Geol 30:285-301

Landais P, Monthioux M, Poty B (1990) Simulation of natural coalification by high-pressure pyrolysis. Int $\mathrm{J}$ Coal Geol $16: 230-234$

Littke R, Büker C, Lückge A, Sachsenhofer RF, Welte DH (1994) A new evaluation of palaeo-heat flows and eroded thicknesses for the Carboniferous Ruhr basin, western Germany. Int J Coal Geol 26:155-183

MacKenzie KJD, Smith ME (2002) Multinuclear solid-state NMR of inorganic materials. Pergamon, Amsterdam

McCann T, Pascal C et al. (2006) Post-Variscan (end Carboniferous-early Permian) basin evolution in Western and Central Europe, in: Gee, DG, Stephenson, RA (Eds.), European Litosphere Dynamics, Geological Society, London, Memoirs 32: $355-388$

Noumi ES, Blin J, Valette J, Rousset P (2015) Combined effect of pyrolysis and temperature on the yield and $\mathrm{CO}_{2}$ gasification reactivity of acacia wood in macro-TG. Energy Fuels 29(11):7311-7318

Opluštil S (2005) The effect of paleotopography, tectonics and sediment supply on quality of coal seams in continental basins of central and western Bohemia (Westphalian), Czech Republic. Int J Coal Geol 64:173-203

Opluštil S, Sýkorová I, Bek J (1999) Sedimentology, coal petrology and palynology of seams and interlying sediments of the Radnice Member in the Kladno Coalfield (Kladno-Rakovník Basin, central Bohemia); their palaeoecological and sequence stratigraphical implications. Acta Universitatis Carolinae, Geologica 43(4):599-623

Opluštil S, Šimůnek Z, Zajíc J, Mencl V (2013) Climatic and biotic changes around the Carboniferous/Permian boundary recorded in the continental basins of the CzechRepublic. Int J Coal Geol 119:114-151

Opluštil S, Schmitz M, Cleal CJ, Martínek K (2016) A review of the Middle-Late Pennsylvanian west European regional substages and floral biozones, and their correlation to the geological time scale on new U-Pb ages. Earth Sci Rev 154:301-335

Pešek J (2004) Late Paleozoic limnic basis and coal deposits of the Czech Republic. Folia Musei Rerum Naturalium Bohemiae Occidentalis, Geologica. Editio Specialis 1, Plzeň, pp. 1-188

Pešek J, Sivek M (2012) Coal-bearing basin and deposits of coal and lignite in the Czech Republic. Czech Geological Survey, Praha

Pešek J, Sýkorová I (2006) A review of the timing of coalification in the light of coal seam erosion, clastic dykes and coal clasts. Int J Coal Geol 66:13-34

Pešek J, Holub V, Jaroš J, Malý L, Martínek K, Prouza V, Spudil J, Tásler R (2001) Late paleozoic limnic basins of the czech republic_-geology and coal deposits. Institute of Geology of the Czech Republic, Praha

Pickel W, Kus J, Flores D, Kalaitzidis S, Christanis K, Cardott BJ, Misz-Kennan M, Rodrigues S, Hentschel A, Hamor-Vido M, Crosdale P, Wagner N (2017) Classification of liptinite-ICCP System 1994. Int J Coal Geol 169:40-61

Šafanda J, Malý L (1994) Paleogeothermal gradient in the boskovice furrow. Stud Geophys Geod 38:37-45

Šafanda J, Žáková B, Buntebarth G (1990) Temperature paleogradient estimations in the Central Bohemian basins. Stud Geophys Geod $34: 208-219$ 
Šafanda J, Suchý V, Sýkorová I, Stejskal M, Filip J, Machovič V, Borecká L, Dobeš P (2003) Thermal history of sedimentary basins of the Czech Republic and its relation to tectonic processes. Acta Montana, Series AB 11(128):45-54

Sarana S, Kar R (2011) Effect of igneous intrusive on coal microconstituents: study from an Indian Gondwana coalfield. Int J Coal Geol 169:40-61

Shi Q, Qin B, Liang H, Gao Y, Qu B (2018) Effects of igneous intrusions on the structure and spontaneous combustion propensity of coal: a case study of bituminous coal in Daxing Mine, China. Fuel 216:181-189

Singh MP, Singh PK (1998) Organic maturation study of the Permian coal seams, Rajmahal basin, Bihar. J Geol Soc India 51:279-294

Singh PK, Rajak PK, Singh VK, Singh MP, Naik AS, Raju SV (2016) Studies on thermal maturity and hydrocarbon potential of lignites of Bikaner-Nagaur basin, Rajasthan. Energy, exploration and exploitation 34(1):140-157, SAGE Publ. Co. Ltd, UK

Smith ME, van Eck ERH (1999) Recent advantages in experimental solid state NMR methodology for half-integer spin quadrupolar nuclei. Prog Nucl Magn Reson Spectrosc 34:159-201

Stach E, Mackowsky MT, Teichmüller M, Teichmüller R (1982) Stach's textbook of coal petrology. Gebrüder Borntraeger, Berlin

Straka P (2016) Characterization of aluminum(III) complexes in coal organic matter. Am J Anal Chem 7(4):378-394

Straka P, Havelcová M (2012) Polycyclic aromatic hydrocarbons and other organic compounds in ashes from biomass combustion. Acta Geodynamica et Geomaterialia 4(168):481-490

Straka P, Klika Z (2006) Identification of aluminium complexes in coal by solid-state NMR spectroscopy. Chemické listy 100:363-367

Straka P, Náhunková J (2009) Temperature conditions of coal formation. Acta Geodynamica et Geomaterialia 2(154):201-207

Straka P, Náhunková J, Žaloudková M (2014) Analysis of unburned carbon in industrial ashes from biomass combustion by thermogravimetric method using Boudouard reaction. Thermochim Acta 575:188-194

Stukalova IE, Rusinova OV (2007) Thermal alteration of coal in the Khasyn coalfield, Magadan region, Russia. Int J Coal Geol 71:462-470

Sýkorová I, Čermák I, Pašek J (1996) Petrographic examination of weathering of coal matter. In: Kříbek B (ed) Weathering of fossil organic matter. Czech Geological Survey, Prague, pp 61-72

Taylor GH, Teichmüller M, Davis A, Diesel CFK, Littke R, Robert P (1998) Organic Petrology. Gebrüder Borntraeger, Berlin, pp 1-704

Turek V, Marek J, Beneš J, Kořínek M, Kořínková M, Drábek K (1998) La grande encyclopedie des fossils. Libraire Gründ, Paris, pp 1-520, 68-97

Whiticar MJ (1996) Stable isotope geochemistry of coals, humic kerogens and related natural gases. Int J Coal Geol 32:191-215

Xl Meng, Mq Gao, Rz Chu, Gg Wu, Fang Q (2016) Multiple linear equation of pore structure and coal-oxygen diffusion on low temperature oxidation process of lignite. Chin J Chem Eng 24:818-823

Yao Y, Liu D, Huang W (2011) Influences of igneous intrusions on coal rank, coal quality and adsorption capacity in Hongyang, Handan and Huaibei coalfields, North China. Int J Coal Geol $88: 135-146$

Zachariáš J, Pešek J (2011) Fluid inclusion study of carbonatedominated veinlets from coal seams and rocks of the Central and West Bohemian basins, Czech Republic. Acta Geodynamica et Geomaterialia 2(162):133-143

Žák K, Skála R (1993) Carbon isotopic composition of whewellite $\left(\mathrm{CaC}_{2} \mathrm{O}_{4} \cdot \mathrm{H}_{2} \mathrm{O}\right)$ from different geological environments and its significance. Chemical Geology (Isotope Geoscience Section) 106:123-131 